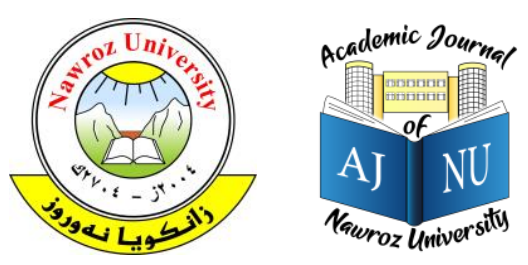

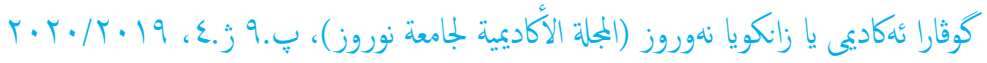

حقوق الطبع والنشر (2017. هذه مقالة الوصول اليها مفتوح موزعة تحت رخصة

e-ISSN: 2520-789X ،CC BY-NC-ND 4. 0. - المشاع الايداعي النسبي

https://doi.org/10.25007/ajnu.v9n4a878

\title{
القراءة القرآينة التي قرأ بها الأخفش الأوسط في كتابهِ معاني \\ القرآن جمع و توجيه
}

د.اسيل سعدالدين شمس الدين، قسم اللغة العربية، فاكلتي التربية، جامعة كيه، كردستان العراق

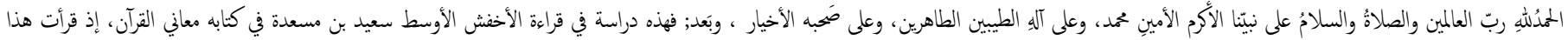

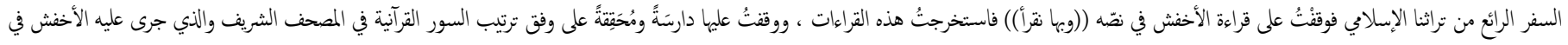

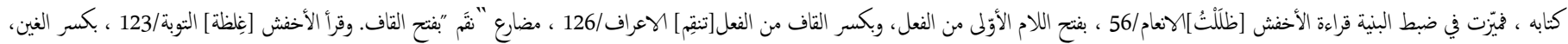

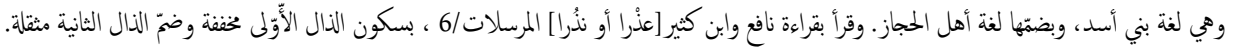

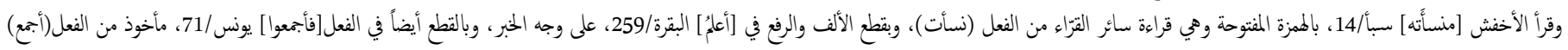

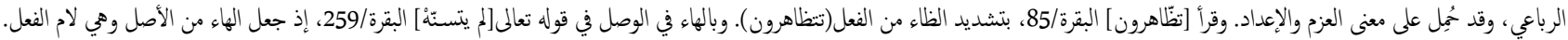

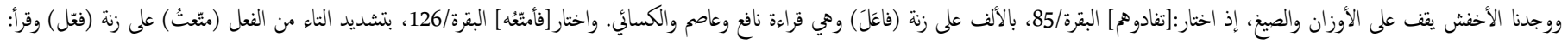

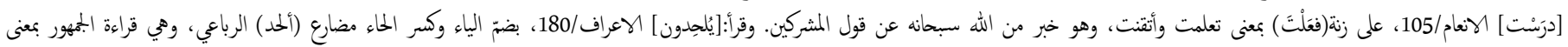

(يعترضون).

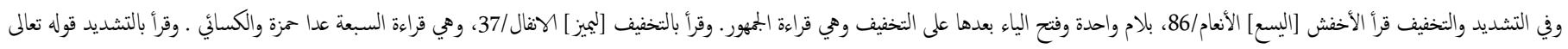

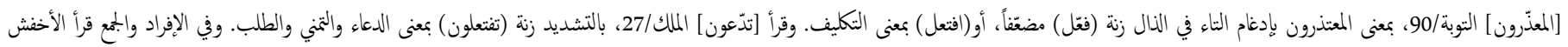

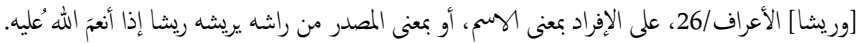

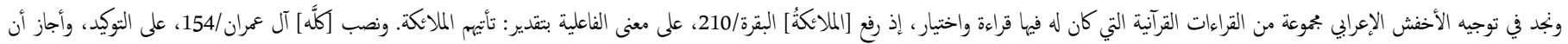

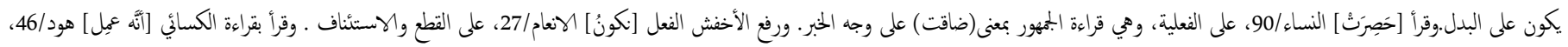

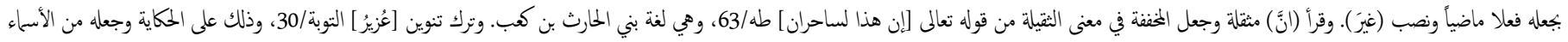

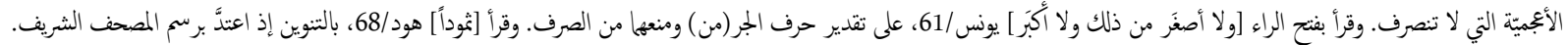

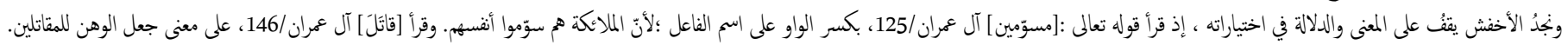

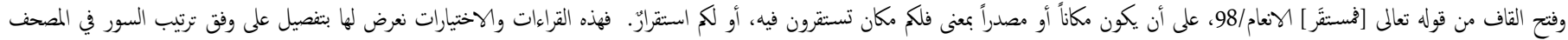

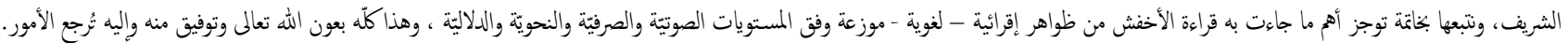

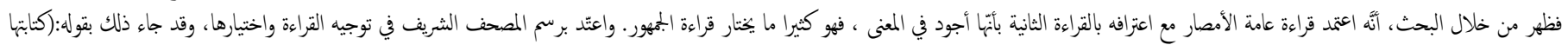

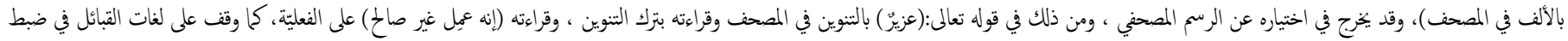

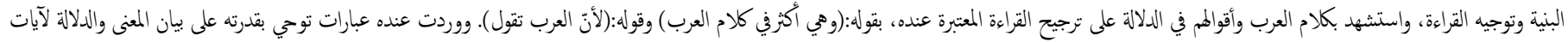

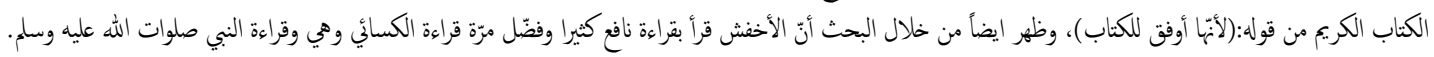

الكلمات المفتاحية: المعنى ، توجيه ، سعيد ، بها نقراً ، مستويات .

1. مقدمة

590/1). تمييزا له عن الأخفش الأكبر:(أبي الخطاب عبد المميد بن عبد المجيد)،أحد شيوخ سيبويه ، والأخفش الأصغر:(أبي الحسن علي بن سليمان)من تلامذة المبرّد ، (الأنباري، (د.ت) صفحة 43و248 )،فهوأحد الأخافش الثلاثة المشهورين

(السيوطي، 1326 صفحة 590/1)
سعيد بن مسعدة وكنيته ((أبوالحسن))،وقد لقب بـ ((الأخفش الجماشعي))، ينظر: (ابن النديم، 1978 صفحة 83)و (الأنباري، (د.ت) صفحة 133) ،وقد كان مولى بني مجاشع بن دارم، (السيوطي، 1326 صفحة 590/1) ،ولقب ((البلخي))؛لأنّه كان من أهل بلخ، (السيوطي، 1326 صفحة 590/1)،ويقال له الأخفش الراوية، (الزبيدي، (د.ت) صفحة 74) ، ولقب بـ ((الأخفش الأوسط)) (السيوطي، 1326 صفحة 


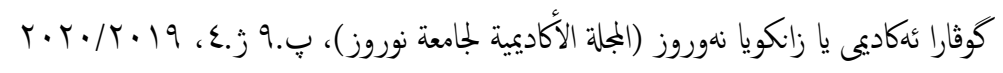

وأقواله لدى العلماء المعاصرين له والذين جاؤا من بعده ،سواء آكانت آراء نخويّة 0

اختلف في تأريخ وفاته ،ولكنها مصصورة في المدة مابين (207-225هـ،أي خلال العقد الأوّل أو الثاني من القرن الثالث للهجرة وأشهر الأقوال في سنة وفاته(215هـ )،ينظر: (السيوطي، 1987 صفحة 83/1و 436/2) و (السيوطي، 1326 صفحة

O(258

أمّا عقيدته فكان معتزليا ،ققد وصفه أبو الطيب اللغوي (ت351هـ) بأنّه من القائلين بالعدل ،ينظر : (أبو الطيب، (د.ت) صفحة 68) وكذلك السيوطي حيث أكد نسبته إلى مذهب الإعتزال بقوله :((وأخذ النحو عن سيبويه جاعة ،برع منهم أبو الحسن سعيد بن مسعدة الأخفش المجاشعي ،من أهل بلخ ،وكان غلام أبي شمر ،وعلى مذهبه في الإتزال )) (السيوطي، 1987 صفحة 405/2) ،وكذلك ذهب المحدثون إلى هذا الرأي ،ومنهم الدكتور عبد الأمير الورد ،ينظر: (الورد، 1975 الصفحات 61-62)، وكذلك الدكتور فائز فارس الذي أثبت أيضا نسبته إلى مذهب الإعتزال في مقدمة تحتيقه ل(معاني القرآن للأخفش)،ينظر: (الأخفش، 1981 صفحة

$0(95 ، 39 ، 38 ، 22$

\section{2. كتاب "معاني القرآن "للأخفش الأوسط}

من أوائل الكنب المصنفة في معاني القرآن الكريم ويصنف ضمن كنب التفاسير اللغويّة ،فقد شرح الأخفش عددا كيرا من المعاني الغامضة التي يصعب فهما على أكثر الناس ،كما ضم الكتاب الكثير من القراءات القرآنية مع توجيها ،ولهجات القبائل العربية والكثير من المسائل النحويّة والصرفيّة ،وكان السماع العنصر المهم الذي بنى عليه كتابه ، فهو كتاب ذو فائدة كيرة وممة لبيان بلاغة ،وغنى ،وتفرد اللغة العربيّة خاصة في

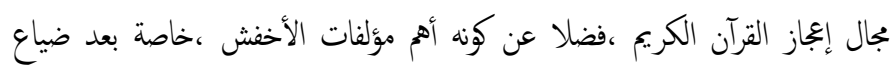
مصنفاته في الصرف والنحو ،ينظر-مقدمة المحقق-: (الأخشف، 1981 صفحة 57)، وتذكر كتب الترامج والطبقات أنّ معاني الأخفش كان الأساس والإمام الذي عمل عليه الكسائي كتابه ،وعمل الفراء كتابه عليها (السيوطي، 1326 صفحة 258) و (الزبيدي، 1973 الصفحات 74-75)، ويؤيد ذلك قول محق كتاب المعاني الدكتور فائز في مقدمته: ((إنَّه مصدر إقتبس منه العلماء السابقون وأثروا به مؤلفاتهم من المعجات والتفاسير وكتب القراءات والنحو وأهمات كتب الدراسات القرآنية واللغويّة
والأخفش معناه صغير العينين ،ولم يكن منفردا بهذا اللقب ،فقد ذكر السيوطي في المزهر أحدعشر نحويا من الأخافش (السيوطي، 1987 الصفحات 453/2-454)

$$
\text { ،وفيهم النحوي ، واللغوي ، والقارئ ، والفقيه . }
$$

ولم ييق عدد الأخافش على ماهو عليه عند السيوطي ،وإنما زاد عددهم وهذا ماذكره الدكتور عبد الأمير الورد بدراسته الموسومة ؛ (منهج الأخفش الأوسط في الدراسة النحويّة ) فصاروا ستة عشرأخفشا ،ينظر: (الورد، 1975 الصفحات 138-139) حاز أبو الحسن على ثقة الحكام والعلماء ؛لأنّه تميز بخصال وصفات أهلته لأن يكون علما مرموقا من أعلام البصرة الذين رفعوا شأنها وأذاعوا علمها بيّن الناس ،فكلن ستمتع بجرأة أدبية ميزة ،وكان حاد الذكاء ثاقب البصيرة ،مناقشا ومخالفا أحيانا لعلماء عصرة ينظر: (الزبيدي، 1973 صفحة 70) و (ضيف، 2008 صفحة 95)حتى عده البعض

$$
\text { المؤسس الحقيقي للمذهب الكوفي (رواي، } 2003 \text { صفحة 278) }
$$

لذالك أثنى عليه العلماء ثناءً كبيرا ،فقال فيه الكسائي (ت189ه()))م يكن في القوم(يعني البصريين) أعلم من الأخفش ، نبهم على عوار الكناب وتركهم (يعني كتاب سيبويه)) (أبو الطيب، (د.ت) صفحة 68)،وقال فيه الفراء ،لما دخل على سعيد بن سالم ،ووصفه بأنّه سيد أهل اللغة وسيد أهل العربية: ((أمّا دام الأخفش يعيش فلا))، (الموي صفحة 227/11)،وقال فيه المبرد (ت285هـ): ((وهو الذي تكلم على كتاب سيبويه ،وشرحه ،وبينه ،وهو معظم في النحو عند البصريبن والكوفيين )) (أبو الطيب، (د.ت) صفحة 68)، وكذلك كانت آراء وشخصية الأخفش العلمية محط إعجاب واحترام ابن جني ،فقد إقتبس الكثير من آراء الأخفش وضمنها في كتبه وكان يصدرها بقوله :(أمّا أبو الحسن)،و(قال أبوالحسن)،و(امتنع أبي الحسن ) ينظر: (ابن جني، 1952 صفحة 116،60/1و308/3) ،ووصفه ابن خلكان وأبو العحاد الحنبلي بأنه ((إمام العربية ))،ينظر: (ابن خلكان، 1977 صفحة 380/2)و (ابن عاد، (د.ت) صفحة 0) م (36/2 ولم يختلف المحدثون في وصف الأخفش ،فقد وصفه الدكتور شوقي ضيف بأنه : ((أكبر أمثمة النحو البصريين بعد سيبويه ،وفي رأينا إنهّ هو الذي فتح أبواب الخلاف عليه ،بل هوالذي أعدَّ لنا فيا بعد مدرسة الكوفة ،ثم المدارس المتأخرة المختلفة ،فإنّه كان عالما بلغات العرب وكان ثاقب الذهن وحاد الذكاء))، (ضيف، 2008 صفحة 95) ،ومام سبق يظهر جليا مكانت الأخفش بين علماء عصره والأثر الكبير الذي تركته آراؤه 


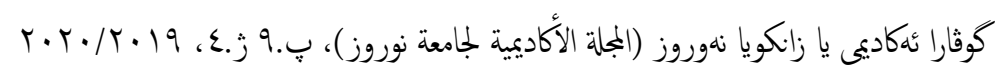

1.2

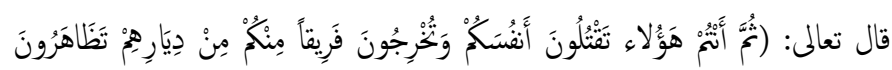

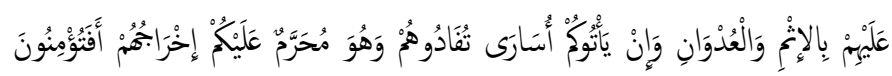

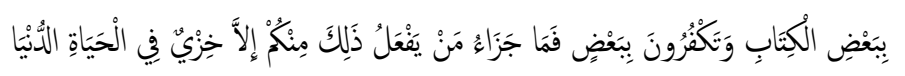

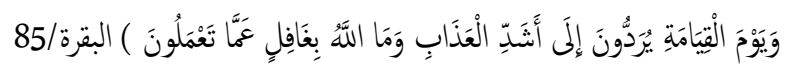
قرأ الأخفش بتشديد الظاء في (تَظًاهرُونَ) بإدغام التاء في الظاء والأصل فيه:تتظاهرون بتائين. قال الأخفش:( ( فجعلها من (تتظاهرون) وأدغز التاء في الظاء، وبها نقراً ،وقد قرئت (تظاهرون) مخففة بجذف التاء الآخرة لأنّا زائدة لغير معنى))

(الأخفش، 1981 صفحة 128)وينظر: (الداني، 2005 صفحة 163). والقراءة بالتخفيف على الحذف في الثانية لحصول الثقل بها، ولعدم دلالتها على معنى المضارعة ، ويرجع المعنى فهيا إلى المعاونة والتناصر من المظاهرة ، كأن كل واحد منهم يسند ظهره للاخر ليتقوى به، فيكون له كالظهر، والآية تدل على الظلم كما هو محرم فإعانة الظالم على ظلمه محرمة. والأصل تتظاهرون ،بناءين ،فاستثقلوا اجتماع التائن سيا مع حرف مقارب لما في المخرج وهو الظاء ،فذفوا التاء الثانية كراهة اجتماع المثليين مع المقارب ،وإنّا حذفوا الثانية دون الأوّلى عند سيبويه ؛لإنَّ هذه الثانية هي التي يلحقها الإعلال بالإسكان والإدغام في الماضي ثم إن الأولى جاءت لمعنى المضارعة ،فلو حذفت لزال ذلك المعنى ـ وعلّة من شدّد أنَّهُ كه الحذف ـ فأدخ التاء الثانية في الظاء ،فزال لفظ التكرير ، وحسن ، الإدغام لأنّك تبدل من التاء في الإدغام حرفاً أقوى من التاء ،وهو الظاء. ينظر: (القيسي، 1981 صفحة 250/1) و (أبو مريم، 2009 صفحة 186). وذهب الطبري إلى أن القراءتين مستفيضنان في الأمصار متفقتا المعنى فقال:(وهاتان القراءتان وإن اختلفت الفاظها فإنها متفقتا المعنى، فسواء بأيّ ذلك قرأ القارى لأنّها جميعا لغتان معروفتان وقراءنان مستفيضتان في أمصار الإسلام بمعنى واحد ليس في إحداهـا معنى تستحقّ به اختيارها على الأخرى إلاّ أن يختار مختار تظّاهرون المشّددة طلبا منه تنمّة الكلمة)) (الطبري، 2001 صفحة 561/1).وينظر: (السمين، 1994 صفحة 285/1)

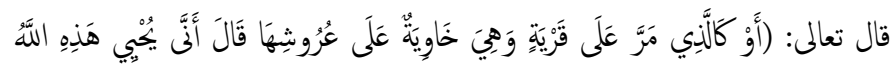

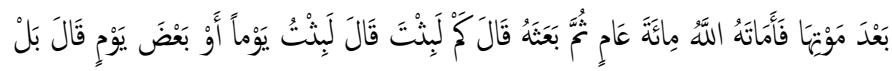

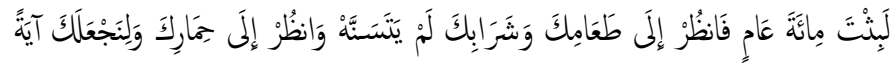

تحوي نقولات شتى منه ،لقد لجأ إليه الكسائي والفراء ، وأفاد منه ثعلب ، والفارسي وابن جني ، وابن برهان ، وأبو حيان ، والزخشري، والجوهري ، وابن منظور وغيره

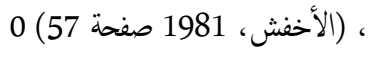
ويرى الدكتور عبد الأمير الورد أن تأريخ تأليف كناب المعاني هو بين سنتي تسع وسبعين ومئة ،وإثنتين وثمانين ومئة .وهما السنتان التي تقدر بينها وفاة سيبويه. ينظر: (الورد، 1975 الصفحات 138-139).

ومما سبق تتضح أهمية معاني الأخفش ،فهو موسوعة ؛لأنهّ إشتمل على تفسير ، ولغة ، ونحو ، وصرف، ودلالة وإلمام واسع في القراءات واللهجات ، وهو كتاب لغة أكثر من كونه تفسير، وما زال مصدرا محا قديما وحديثا للدارسين والكتاب لينهلوا من مكنوناته التي صدرت عن أحد كبار أئمة العربية ألا وهو الأخفش الأوسط سعيد بن

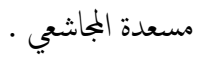
وهذا البحث يقوم على دراسة في توجيه قراءة الأخفش الأوسط في كتابة معاني القرآن ، فبعد قراءة هذا السفر الرائع من تراثنا الإسلامي،وقفت على قراءة الأخفش في نصّهِ (وبها نقرأ) فاستخرجت هذه القراءات ، ووقفت عليها دارَِّة ومُحقِّقِة على وفق ترتيب السور القرآنية في المُصحف الشريف، والذي جرى عليه الأخفش في كتابه، على المستويات الصوتيّة ، والصرفيّة ، والنحويّة ، والدلاليّة، فيّزت في ضبط البنية ، والأوزان والصيغ ، والتشديد والتخفيف ، وتوجيه الأخفش الإعرابي لمجموعة القراءات القرآنية والتي كان له فيها قراءة واختيار، إذ رفع (الملايكِكُ)البقرة/210،على معنى الفاعلية بتقدير: تأتيهم الملايكة ،ونصبَ (كلمّ) آل عمران/154 ، على التوكيد، وأجاز أن يكون على البدل، وقرأ (إنَّ) مثقلة وجعل الخمفة في معنى الثثيلة في قوله تعالى :(إن هذان لساحران/طه/63،وهي لغة لبني الحارث بن كعب، وترك تنوين(عزير) لتوبة/30 ، وذلك على الحكلية وجعله من الأسهاء الأجمية التي لا تنصرف. ونجدُ الأخفش يقف على المعنى والدلالة في اختياراته. إذ قرأ قوله تعالى:(فستقر) الأنعام/98 ، على أن يكون مكاناً أو مصدراً بمنى فلكم مكان تستقرون فيه ، أو لكم إستقرار، ومن دِلالة الككثة وقراءة العامة قرأ الأخفش (طائف) الأعراف/201 ، بالألف لإجحاع القَّاء عليها، وهي بمنى الغضب والذلة وتكون من المطيف به ....... 


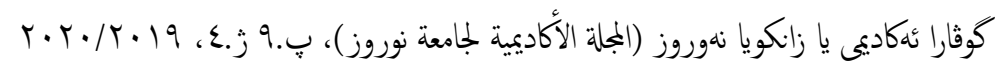

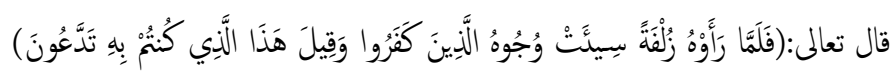
27/ الملك

قرأ الأخفش "تدَّعُون بالتشديد زنة " تقتعلون من الدعاء بما يتمنون ويسألون ويطلبون، وقراءة التخفيف بسكون الدال مؤيدة أيضا للقول بأنهّا من الدعاء. قال الأخفش: ((فقيل هم حين رأوا العذاب : هذا الذي كنتم به تَدْعَونَ - خفيفة و (تدَّعون) ثقيلة، قرأه الناس على هذا المعنى، وهو أجود، وبه نقراً ؛ لأنّه شئ بعد رون شئ)) ـ (الأخفش، 1981 صفحة 502/2)، وينظر: (ابن غلبون، 1991 صفحة 593/2)و (القيسي، 1988 صفحة 747) (ابن عادل، 1998 صفحة 258/19). وجعل الفرّاء التخفيف والتشديد سواء في المعنى فقال:(يريد: تَدْعون وهو مثل قوله: تَذكرون وتذّكون وتخبرون وتختبرون، والمعنى واحد والله أعلم)) . (الفراء، 2001 صفحة 171/3). وذهب الزجاج إلى أنَّ التخفيف من الدعاء والتشديد من الكذب ونب والباطل، فقال:((وقُرئت (تَدعُون) من دعوت أدعو، فأمّا تدّعون، فجاء في التفسير: تكذَبون، وتأويله في اللغة: هذا الذي كنتم من أجله تدّعون الأباطيل والأكذيب، أي:

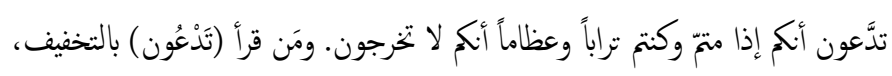

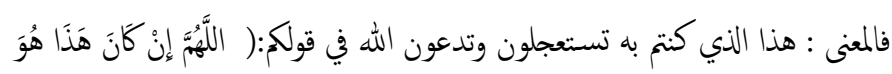

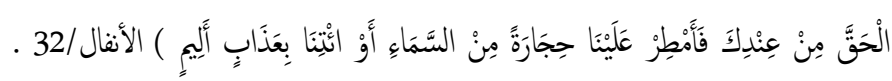
ويجوز أن يكون معنى تدّعون هذا أيضا: تقتعلون، من الدعاء، وتثنعلون من الدعوى يجوز ذلك، والله أعلم)) . (الزجاج، 2004 صفحة 157/5)وينظر: (أبو مريم، 2009

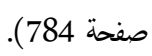

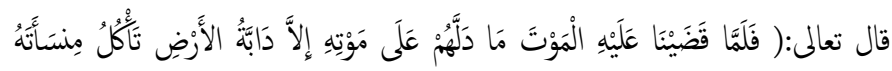

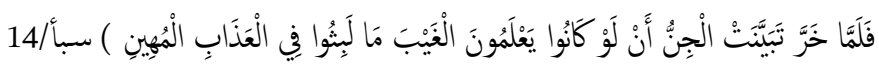
قرأ الأخفش" مِنسانَّهُ" بالهمز مأخوذة من" نَسَأثُ" ، وقد استشهـ بأقوال العرب

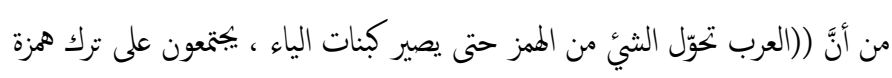

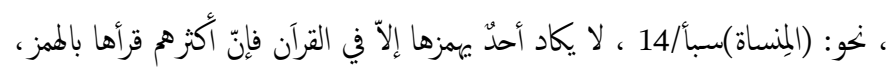
وبها نقرأ، وهي من" نَسَأتُ" )). (الأخفش، 1981 صفحة 100/1). وينظر: (ابن مجاهد، 1972 صفحة 527)و (ابن خالويه، 1999 صفحة 187) و (القرطبي، 1988

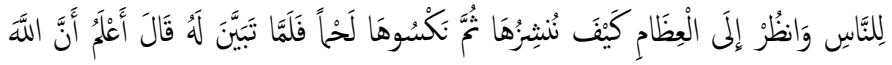
عَلَى كُلِّ شَيْيٌ قَدِيقٌ ) البقرة/259 قرأ الأخفش ((لم يتسنّهُ))بالهاء في الوصل، وذذك أنّ مِن القّراء مَنْ يحذفها في

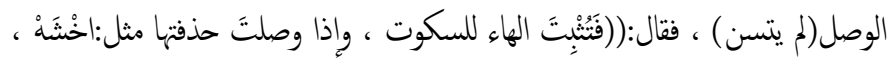
وأثنهها بعضهم في الوصل فقال:(لم يتستنهُ وانظر ) جُعل الهاء من الأصل، وذلك في المعنى : لم تَمرر عليه السنون، فالسنة منهم من يجعلها من الواو، فيقول : سُنِّهُ ، ومنهم من يجعلها من الهاء فيقول : سُنيهة يجعل الذي ذهب منها هاء، كأنه أبدلها من الواو، كما قالوا: أسنتوا، إذا أصابتهم السنون ، أبدل التاء من الهاء ، ويقولون : بعته مساناة ومسانهة ويكون (لم يَتَسنبّهُ أن تكون هذه الهاء للسكوت، ويحمل قول الذين وصلوا بالهاء على الوقف الخني، وبالهاء نقرأ في الوصل)) (الأخفش، 1981 صفحة (182/1

فن حذف الهاء في الوصل وأثنها في الوقف جعل الهاء في ((يتسنّهُ)) زائدة صلة وحشوا، والأصل فيها تسنيت تسنيا، وذلك بأنّ السنة تجمع سنوات ، ومَن أثبت الهاء في الوصل والوقف جعل الهاء في ((يتسنّه)) لام الفعل ويجعلها مجزومة ؟(لم))

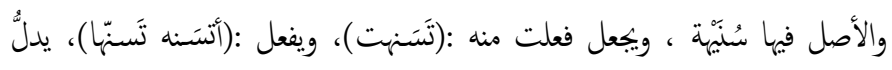

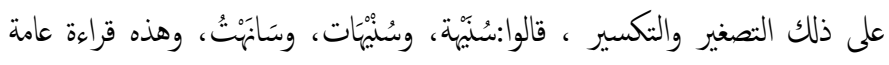
قراء أهل المدينة والحجاز، وتقول: أسنهت عند القوم وتسنّت عندهم ، إذا أقتت سنة. (قرأ المززة والكسائي "م يتسنّهُ "بالهاء وقفا وبحذفها وصلا، والباقون باثثباتها في الحالين ينظر: (الفراء، 2001 صفحة 304/2) و (أبو حيان، 1990 صفحة 304/2) و (أبو مريم، 2009 صفحة 218). وصّوب الطبري القراءة باثثبات الهاء في الوصل والوقق، وهي قراءة عامة أهل الحجاز والمدينة، فقال: ((والصواب من القراءة عندي في ذلك إثبات الهاء في الوصل والوقف؛ لأنهّا مثبّتة في مصحف المسلمين ، ولإثبانها وجه صحيح في كلنا الحالتين في ذلك)). (الطبري، 2001 صفحة 353/3)وينظر: (خميس، 1996 صفحة 311)،ومعنى قوله :(لم يتسنه ) - من لفظ السَنَة - لمُ يَتغِّر بمرِّالسنين عليه ،أي بتي على حاله .ينظر: (ابن أدريس، 2007 صفحة 115/1) 


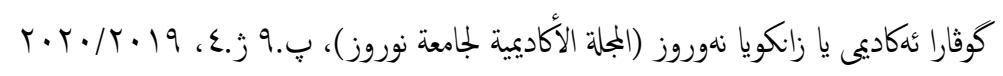

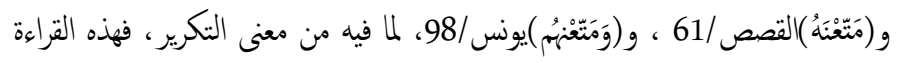
أوّلى وهو الإختيار وهي قراءة أبيّ والحسن ومجاهد وأبو رجاء والجحدري وعيسى بن عمر وعليه قراءة العامة من الأمصار. ينظر: (الطبري، 2001 صفحة 108/2)و (القيسي، 1981 صفحة 265/1) ، ووجه التخفيف وهي قراءة ابن عامر؛ لأنه جعله من أمتع، فإن أمتعه ومتعه واحد، كأفرحه وفرحه وهي لغة في كلام العرب.ينظر : (أبو مريم، 2009 صفحة 193) و (القيسي، 1981 صفحة 265/1). فالله سبحانه تعلى قال ذلك لإبراهيم جوابا لمسألنه ما سأل من رزق الثمرات لمؤمني أهل مكة ، فكان معلوما بذلك أنَّ الجواب إنّا هو فيا سأله إيراهيم لا في غيره. ينظر: (ابن عادل، 1998 صفحة 473/2). (ابن

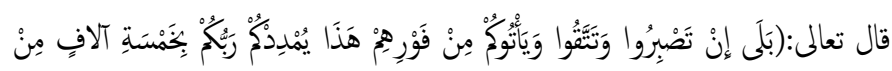

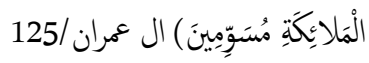
قرألأخفش(مُسوَّمين)بنتح الواو وهي قراءة مصضم القراء ،اسم مفعول من

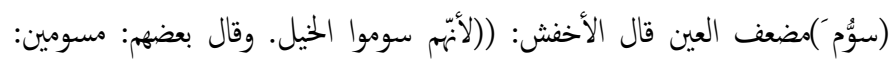
معلمين ،لأنهّ هم سوموا، وبها نقرأ )) (الأخفش، 1981 صفحة 215/1)، وينظر: (ابن عادل، 1998 صفحة 522/5) . والسمة العلامة ،على معنى أنّ غيرهم من

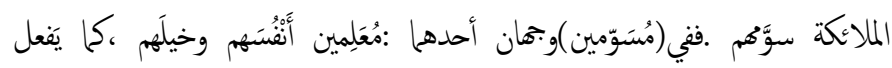
الأبطال ذلك بريشة ،أوصُوفة ،أو ِعصابة صفراء ،أوحمراء وما شابه ذلك ،و الثاني

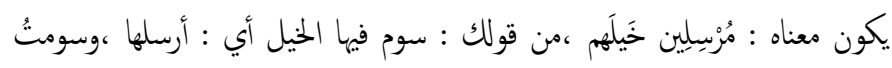

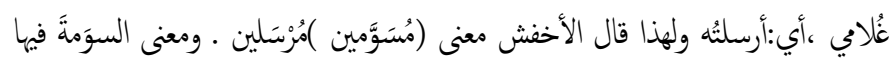
:أنّ الله تعالى سوَمَهُم ،أي :جعل عليهم علامة ،وهي العائم ،أو أنّ الملانكة جعلوا خيلهم نوعا خاصا - وهي البلق - فقد سوموا خيلهم ينظر: (ابن أدريس، 2007 الصفحات 168/1-169)و (الخياط، 2006 صفحة 160/2)، فأما كسر الواو وهي قراءة ابن كثير وأبوعمرو وعاصم ويعقوب (مُسَوِمين) فعلى اسم الفاعل من (سوّم) مضعف العين أيضا ،ويحتمل الوجهين : مُرْسَلين كما ثُرُسَلُ الإبل والحيل للمَوَّم .والآخر مُعلمّين .والقراءة بكسر الواو أوّلى ؛ملا جاء في الخجر :أن رسول الله (صلى الله عليه وسلم)قال يوم بدر :(سوموا فإن الملانكة قد سومت) (المهدوي، 1995 صفحة 231/1)،وقد كانت الملائكة سوّمت يوم بدر بالصوف الأبيض في نواصي الخيل وأذناهيا ،فَنسبب الفعل إلى الملايكة فدلّ على وجوب كسر الواو في مُسَوِّمين ينظر: (أبو مريم، 2009 صفحة 244) و (محسن، 1989 صفحة 119/2)، والقراءتان
وذكر الفرّاء أنَّ أهل الحجاز لم يقرؤوها مهموزة لأنهم ربّّا أرادوا لغة قريش الذين يترون الهمز ، وأورد زع الرؤاسي له أنّه سأل عنها أبا عمرو فقال: (مِنساته) بلا هزز ، إذ إنّه لم يعرفها فترك هزها. (الفراء، 1999 صفحة 356/2)،ولا أظنّها حجّة توجب ترك هزها. وإنَّ المشهور والمُجمع عليه (مِنْسأَته) و(منساته) بالهمز وبالبدل من الهمز ، وهي العصا، مِفُعَاةٌ من نَسَأت الناقة والبعير إذا زاجرته. وقد وقف الأزهري عند قراءة أبي عمرو (مِنْساته) بلا همز ، وقراءة ابن عامر(مِنْسَتْه) بالهمزة الساكنة ، وذكر أنّ القراءة الجيدة فيها بالممزة المفتوحة وهي قراءة سائر القزّاء. قال أبو منصور: ((أمَّا قراءة أبي

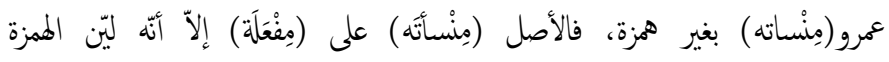
فقال:مِنْستاته، وهو يريدها. وأمَّا قراءة ابن عامر (مِنْأته) بهمزة ساكنة فليست بجيدة، وأجود القراءات في هذه الحروف (ِِنْاتَتة) أي عصاه ، من نَسَأثُ البعير إذا سقته بالعصا)). (الأزهري، 1999 صفحة 391)، وينظر: (النحاس، 2004 صفحة 40/5)و (الزخشري، د.ت. صفحة 204/2)،فالحجة لمن هز :أنّه أتى باللفظ على أصل الإشتقاق ،ولثبوتها تواتراً ،وهي محكية عن العرب؛ولأنَّ العصا سميت بذلك ،لأنَّ الراعي ينسيء بها الإبل عن الحوض ،أي يؤخرها .وتجة من ترك الممز إنّّ أراد التخفيف ،وها لغتان بمعنى واحد ،والأصل الممز. ينظر: (ابن أدريس، 2007 صفحة 709/2)و (خميس، 1996 صفحة 530).

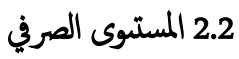

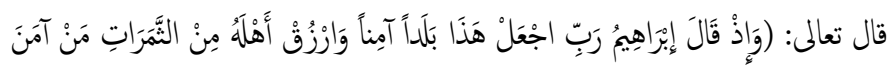

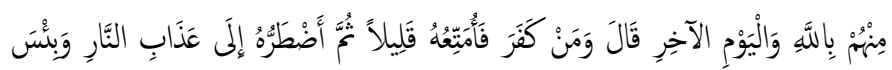

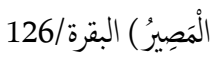

قرأ الأخفش ((فأمتِعُُ))بتشديد التاء من الفعل((متّعتُ))، وهوقول الربّ تعالى ذكره، ومن خفّف الفعل وقال((فأمنتعُه ))فهو من الفعل (أمتنعتُ) وذلك على قول إبراهيم عليه السلام يسأل ربّه إنّ من كفر فأمتنعه قليلا، قال الأخفش: ((وقال:(ومن كفر

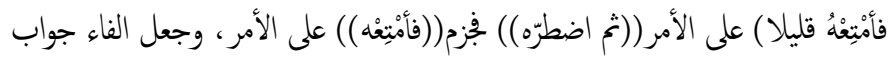
المُجَازاة. وقال بعضهم: فأمتتعُُّ، وبها نقرأ، رفع على الخبر وجواب المجازاة الفاء)) (الأخفش، 1981 الصفحات 147/1-148) وينظر: (ابن جني، 1386 هجري صفحة .$(104 / 1$

وصوّب الطبري قراءة التشديد، على أنّه من متع دون أمتع؛ لأنَّكل ما في القران من هذا النظم فهو على لفظ التمتيع دون الإمتاع نحو:(يُتبّكُم)هود/3، 


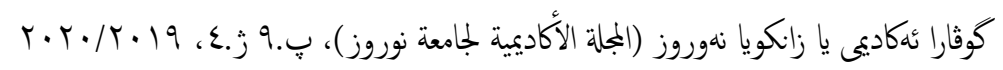

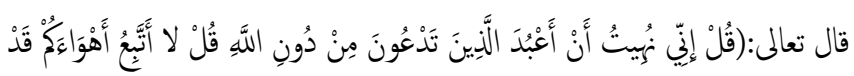

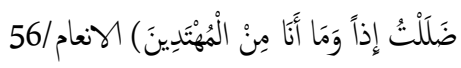
قرأ الأخفش" ضَللْتُ "بفتح اللام الأوّلى من الفعل ،مضارع " يَضِلُّ "ومن قرأ بكسر اللام ، فضضارعه" "يَضَلُّ" . قال الأخفش:(وقال بعضهم: وهما لغتان : من قال

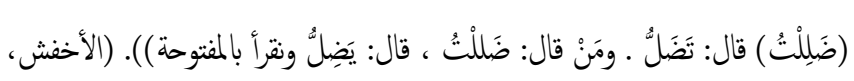

(276/2 1981 صفحة

وقرأ الطبري بقراءة الأخفش وعامة قراء الأمصار ، وهي اللغة الفصيحة عنده، فقال: ((وللعرب في (ضللت) لغتان: فتح اللام وكسرها ، واللغة الفصيحة المشهورة هي وتهري

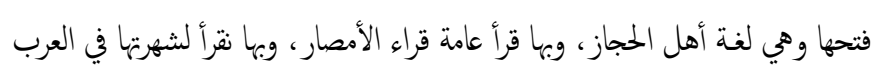
، وأمّا الكسر فليس بالغالب في كلامها، والقراء بها قليلون)). (الطبري، 2001 صفحة

275/5)،وينظر: (ابن عادل، 1998 صفحة 181/8)

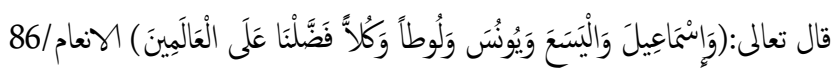
قرأ الأخفش ((اليَسع)) بلام واحدة وفنح الياء بعدها على التخفيف ،وهي قراءة جمهور القراء ـوقراً جاعة من القراء الكوفيين ومنهم حمزة والكسائي "اللّنستع "بلامين وبالتشديد. قال الأخفش: ((وقال بعضهم" اللّنّعَع ونقرأ بالخنيفة)) (الأخفش، 1981 صفحة 281/2)،وينظر: (ابن مجاهد، 1972 صفحة 262)، (الجزري، د.ت. صفحة

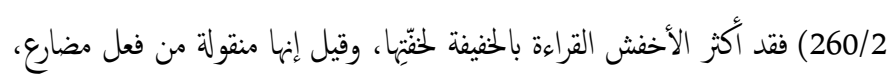
والأصل فيه " يوَتَعُ "مثل "يوْعَدُ "، وزيدت فيه الالف واللام، وقيل: أنّ الالف واللام فيه للتعريف، كأنه قدر تنكيره. واليسع هذا هو يوشع بن نون فتى موسى عليه السلام، وهو اسم أنجمي لا إثتقاق له. وأصله في العبرية (إل +يشَعْ)ومعناه الله وسيع قهو اسم أبجمي مُفسنر في القران بالتعريب وحده ،إنّه (إلْ+يََع)على أوزان العربيّة، يكون معناه :الله واسعٌ عليٌّ سبحانه (أبو سعده، 1993 الصفحات 170/2174).يقول الفراء في زيادة الألف واللام على العلم الذي على وزن الفعل(العرب إذا فعلت ذلك فقد امسَّت الحرف مدحا (الفراء، 2001 صفحة 342/1). واختارالطبري قراءة التخفيف فقال: ((والصواب من القراءة في ذلك عندي قراءة من قرأه بلام واحدة مخفقة، لإجحاع أهل الأخبار على أنَّ ذلك هو المعروف من اسمه دون التشديد ، مع ائه اسم أنجميّ، فينطبق به على ماهو به. وإنّا لا يستقيم دخول الألف واللام فيا جاء من أسهاء العرب على" يفعل "، وأمّا الاسم الذي يكون أججمياً فإنما
مُختارتان (ابن أدريس، 2007 صفحة 168/1)، والمتبحر في هاتين القراءتين يِيد إنَّ مردّ الخِلاف راجع إلى إختلاف الصيغ إذ القراءة الأوّلى اسم فاعل والثانية اسم مفعول .

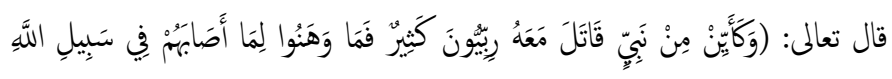

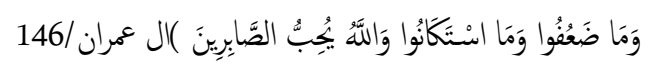
قرأ الأخفش((قاتلَّ)) بفتح القاف والتاء على البناء للفاعل ،وهو مشتق من (القتال) ،وربيون فاعل ،وقد وصفت هذه القراءة بالكثرة فقال:((يجعلُ النبيّ هوالذي قُنل، وهو أحسن الوبهين؛ لأنّه قد قال:(أفأن مات أوقُتل) ال عمران/144، وقال بعضهم:

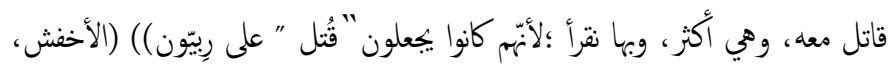
1981 صفحة 217/1) وينظر: (ابن سوار، 2005 صفحة 90/2). وقراءة الأخفش هي قراءة أهل الكوفة وابن عامر بالألف وفتح القاف والتاء وقرأ أهل الحجاز والبصرة((قُتِل))بضم القاف وكسر التاء على البناء المفعول،وهو مشتق من(القتل)،وربيون نائب فاعلينظر: (ابن إدريس، 2007 صفحة 173/1) ،قال

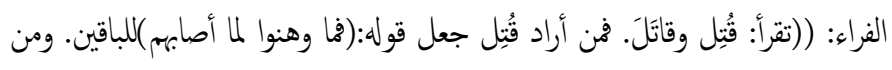
قال: قاتلَّ جعل الوهن للمقانلين)) (الفراء، 2001 صفحة 237/1). وصوّب الطبري قراءة من ضمَّ القاف فقال:((قراءة من قرأ بضم القاف" قُتِلل معله ربيّون كثير "لأنَّ الله عزوجل إنّا عاتب بهذه الآية ، والآيات التي قبلها من قوله: (أم حسبتم أن تدخلوا الجنة وملا يعلم الله الذين جاهدوا منكم) الذين إنهزموا يوم أُحد ، وتركوا القتال أو سمعوا الصائُ يصيح: إنَّ محمداً قد قُتِل، فعذّلم الله عزوجل على فرارهم وتركمم القتال ) ) (الطبري، 2001 صفحة 155/3). ويصلح "قُنِل "أن يرفع ضمير "نبيّ "وأن يرفع رِيبّون "، كما يصلح ذلك في "قاتلَ ". وذهب ابن عطية إلى أنَّ قراءة "قاتل" أعَّ في المدح ؛لأنهّ يدخل فها من قُتِل ومن بقي، والإسناد حينئذ للربيّن ، وعلى قراءة "قُتْل "الإسناد إلى"نبيّ" . وذهب أبو حيان إلى أنَّ "قُتِل" أظهر في المدح ، وهي أبلغ في مقصود الخطاب؛لأنهّا نصّ في وقوع القتل، ويستلزم المقانلة. و "قاتل" لا تدل على القتل ، إذ لا يلزم من المقانلة وجود القتل، فقد تكون مقانلة ولا يقع قتل. (ابن عادل، 1998 صفحة 585/5)، وينظر: (ابن عطية، 1974 صفحة 520/1).والقراءتان حسنتان (الباقولي، 1971 صفحة 166)؛لأنَّ فيها من تنوع المعاني ما تعظم به فائدة الآية وتتسع دلالتها ، والمعاني في كلا القراءتين تكامليَّة وليست تصادُميّة . 


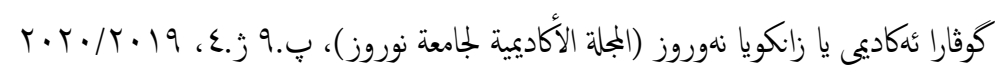

وعاصم وحمزة والكسائي (دَرْستَ)ساكنة السين بغر الف. وينظر: (ابن مجاهد، 1972 صفحة 64) و (الأزهري، 1999 صفحة 164) وعرض الطبري للقراءات فيها ووافق قراءة الأخفش بقوله:(وأولى القراءات في ذلك عندي بالصواب قراءة من قرأه :(وليقولوا درَسْتَ) بتأويل: قرأت وتعلمْتَ، لَأنّ

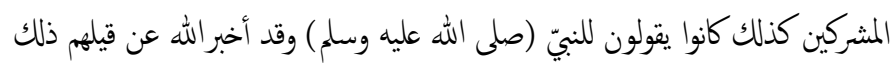

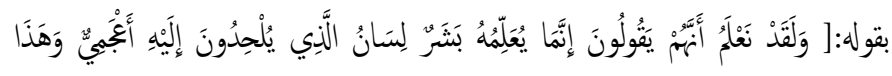

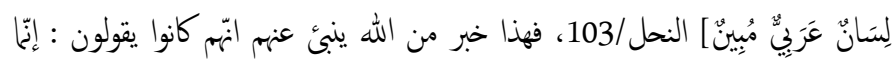

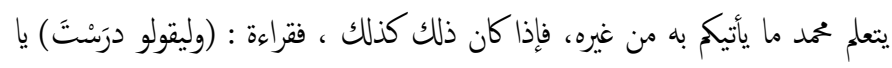
محمد، بمعنى: تعلمت من أهل الكناب ، أشبه بالحت وأولى بالصواب من قراءة من قرأه (دارسُتَ) بمعنى: قارأتهم وخاصمتهم، وغير ذلك من القراءات. (الطبري، 2001 صفحة 398/5)، وينظر: (الفراء، 2001 صفحة 349/1) و (النحاس، 2004 صفحة

. $(347 / 1$

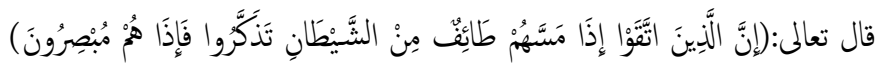
| الهراف/201

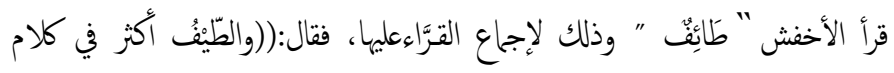
العرب،...، ونقرؤها طائف، لأنَّ عامة القّرّاء عليها)). (الأخفش، 1981 صفحة 316/2)، وينظر: (ابن مجاهد، 1972 صفحة 301) و (ابن الجزري، 2002 صفحة 206/2) ،فالطائف اسم فاعِل من طَافَ يُطوفُ فهو طائفِ ،كقالَ يَقولُ فهو قائِل والطائِف مَاطافَ عليهم من الشيطان:فأمًا (طيف)ففيه قولان لأهل العربيّة :أحدها. :إنّه مصدر من طاف يَطيفُ طَيفا ،هكذا ذكِرعن العرب .وقيل :إنّه من ذوات الواو

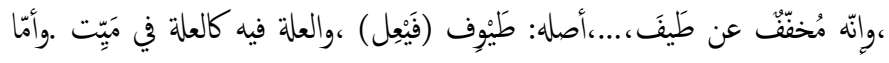
أهل التأويل فلهم فيه أقوال :قال ابنُ عباس :الطّيف :النّزع .وقال:أبوعمرو :الطَّف :الوَسْوَسَة .وقال من بَقي من أهل التأويل الطيف :الخَطرَة واللمّّة ـ (ابن إدريس، 2007 الصفحات 337-336/1) ،فالشيطان يطوف بابن أدَم ليستنِله عن طاعة ربّهِ ، أو ليوسوس له، والوسوسة والإستنزال هو الطائف من الشيطان. قال الكسائي :(الطيف اللمّم والطائف ما طاف حول الإنسان. وطائف بالألف من طاف به إذا دار حوله فهو طايف كذا قال الكسائي. وقال الكسائي في قراءة طيف: هو مخفف من

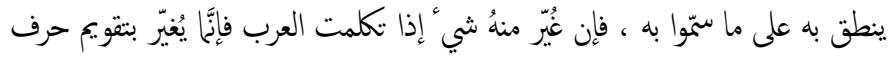
منه من غير حذف ولا زيادة فيه ولا نقصان، واللّنسعَع إذا شدّد لحتّه زيادة لم تكن فيه قبل التشديد. وأخرى أنّه لم يحفظ عن أحد من أهل العلم علمنا أنّه قال: اسمه "ليسع" فيكون مشدّدا عند دخول الألف واللام اللتين تدخلان للتعريف)). (الطبري، 2001 صفحة 341/5) وينظر: (الفراء، 1999 صفحة 342/1) و (القيسي، 1988 الصفحات 260/2-260)، فالعَلم اليسع مُعَّب، جاء موافقا لسُنن العرب في كلاقهم.

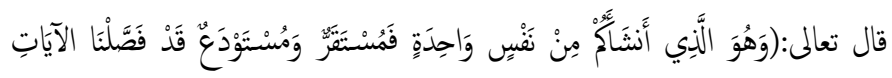
لِقَوَْ يَفْقَهُونَ) الانعام/98 قرأ الأخفش" فَمَستقَّرّ" بفتح القاف فهيها، وذلك أن يكون مكاناً وأن يكون مصدراً، بمعنى: فلكم مكان تستقرون فيه، أو لكم استقرار. قال الأخفش:((فتزاهُ يعني: فهنها

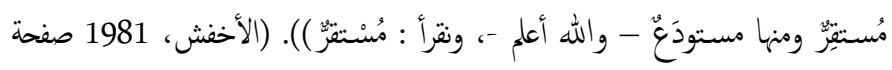
282/2)، وقراً ابن كثير وابو عمرو بكسر القاف والباقون بفتحها،ينظر: (ابن مجاهد، 1972 صفحة 263) و (أبو زرعة، 1974 صفحة 262)

هن كر القاف جعل "مستقزًاً "|سم فاعل، والمراد به الأشخاص، وهو مبتدأ

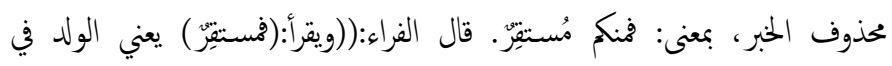
الرم) م) (الفراء، 2001 صفحة 347/1)،(وعرض الطبري للقراءتين ، ورجّح فتح القاف فهيا ليناسب " مستَودع " فقال:((وأولى القراءتين بالصواب عندي وإنّ كان

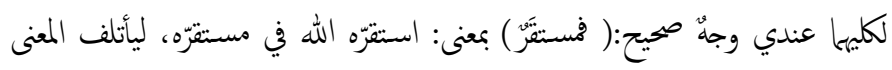
فيه، وفي (المستودَع) في أنّ كلّ واحد منها لم يُسمّ فاعله، وفي إضافة الخبر بذلك إلى الله في أنّه المستقر هذا ، والمستودع هذا وذلك انَّ المجميع بمعون على قراءة قوله:(ومستودَع) بفتح الدال على وجه ما لم يُسمّ فاعله، فإجراء الأوّل، أعني قوله:(فستقَر) عليه أشبه من عدوله عنه)) (الطبري، 2001 صفحة 379/5)، وينظر: (ابن عادل، 1998 صفحة 315/8) و (السمين، 1994 صفحة 136/3).

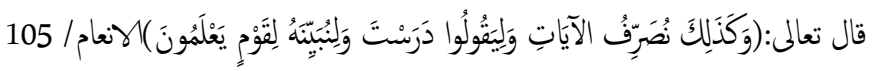

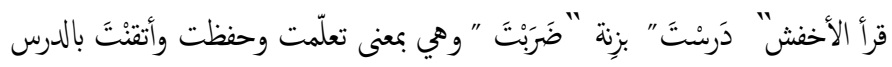
أخبار الأوّلين كما حُكي عنه. قال الأخفش:(وقال بعضهم: دَرسنتَ، وبها نقرأ؛ لأنهّا أوفق للكتاب. وقال بعضهم: دَرَتْت )).(الأخفش، 1981 صفحة 285/2) ،وقرأ نافع 


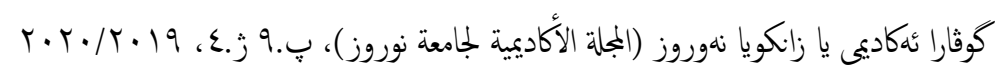

هؤلاه ، وإِّما صفته أنّم كانوا قد اجتهدوا في طلب ما ينهون به مع رسول الله صلى الله عليه وسلم إلى عدوّهم وحرصوا على ذلك فلم يجدوا إليه السبيل، فهم بأن يوصفوا بأنهم قد أعذروا أولى وأحق منهم بأن يوصفوا بأنهم عذروا إذا وصفوا بذلك)). (الطبري، 2001 صفحة 144/10) 0وعرض الأزهري للقراءتين فالقراءة بالتخفيف من الذين جاءوا بعذر ، والقراءة بالتشديد كأنّ لمم عذرا ولم يكن، أوعلى المعنى الأوّل، وذكر أنّ العرب تقول للمقصّر: معذِر. (الأخفش، 1981 الصفحات 212-213) وميّز ابن جنّي عذَّر من أعذر، فقولمم: عذَّر في الحاجة: أي قصّر ، وأعذر: تقدّم (ابن جني، 1386 هجري صفحة 273/1) ،وينظر: (ابن إدريس، 2007 الصفحات 360/1-

وفصّل صاحب اللباب القول في معنى القراءتين ،إذ قرأ المجهور "المعذرون" بفتح العين وتشديد الذال من" فعَّل "مضعفاً، ومعنى التضعيف فيه النكليف، بأنَّ توهم أنّ له عذرا ولا عذر له، أو أن يكون وزنه" إفنعل "والأصل إعتذر، فأدذغت التاء في الذال بأن قلبت تاء الأفعال ذالاً، ونقلت حركها إلى الساكن قبلها، وهو العين ، والأصل فيها: المعتذرون، وإلى هذا ذهب جمهور العلماء ومنهم الأخفش والفرّاء وأبوعبيد وأبوحاتم والزجاج وابن الأنباري، والإعتذار - هنا - قد يكون بالكذب ، وقد يكون بالصدق. ومن قرأ "المُعْذِرون" بالتخفيف بسكون العين وكسر الذال فهي من (أعْذر) يُعْذِر مثل أكرم يُكرِمٍ ، وهم المبالغون في العُذر. (ابن عادل، 1998 صفحة 168/10)، وينظر: (الزخشري، د.ت. صفحة 300/2).

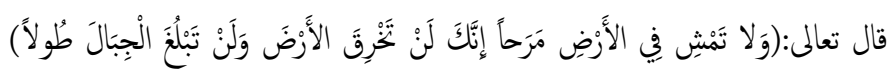

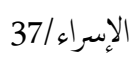

قرأ الأخفش" مَحها " بفتح الراء على إرادة المصدر، إلاّ أنّه حسّن المكسورة الراء على إرادة الوصف باسم الفاعل فقال:((مرَها ومرِحا : والمكسورة أحسنها،لأنكّ لوقلت: تمشي مَرِها، كان أحسن من "تمشي مَزها " ونقرؤها مفتوحة)). (الأخفش، 1981 صفحة 389/2). وذهب الطبري إلى فتح الراء فيها فقال:((وقيل: لا تمشش مزَها، ولم يقل مرِها؛ لأنّه لم

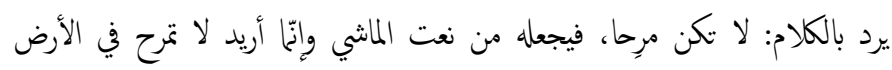
مرَحا)) (الطبري، 2001 صفحة 122/9).
طيّف)). (الكسائي، 1998 صفحة 151)، وينظر: (البيضاوي، 1998 صفحة 47/3) و (القيسي، 1981 صفحة 487/1). وصرّح الأزهري بأنَّ معنى الطيف والطائف واحد، وهو الجنون ، ويأتي أيضا بمنى الخيال في المنام. قال أبو منصور:((المعنى في الطيف والطائف واحد. والطيف في كلام العرب له معنيان: أحدها: الجنون ، ومنه قول الهذلي:(جز بيت من قصيدة لأبي العيال بن أبي غشير في ديوان الهذليين )، (الزين، 1991 صفحة 414/1)

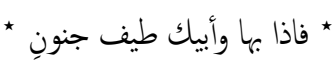

وقد جعله بعض المفتّرين في هذا الموضع جنوناً؛ لأنّ الغضب الشديد يعتريه شيء من الجنون ، المعنى: إذا مسّهم غضب يُشيّل إلى مَنْ رآه في تلك الحالة بعدما رآه ساكناً انّه جنون. والطيف في غير هذا: الخيال الذي تراه في منامك، يقال: طاف الخيال يَطيف طيفاً، وطاف الرجل بالبيت يطوف طوافاً)). (الأزهري، 1999 صفحة 196)وينظر: (262/2 ميسن، 1989 صفحة

وفصّل الطبري القول في معنى الطيف ومعنى الطائف، وذكر الفرق بينها فنهم من جعل الطيف والطائف بمعنى ماكان كالميال والشيء يلمّ بك، وبعض الكوفيين قال: الطائف ما طاف بك من وسوسة الشيطان ، والطيف من اللمّم والمسّ، وقيل: الطيف اللَّم، والطائف كل شيء طاف بالإنسان ، وذكر عن أبي عمرو بن العلاء أنّه كان يقول : الطيف : الوسوسة. وصوّب الطبري قراءة مَنْ قرأ "طائف " ؛لأنّ ((أهل التأويل تأولوا ذلك بمعنى الغضب والزّة تكون من المطيف به)) (الطبري، 2001 الصفحات 106/9-107).

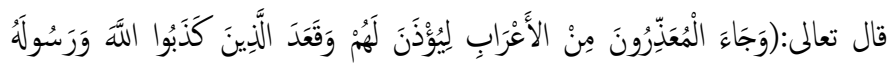

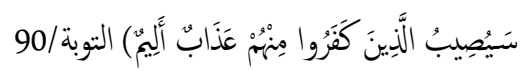
قرأ الأخفش" "المُذِّّون " بالتشديد بمعنى المعتذرون بإدغام الناء في الذال،هكذا قرأت السبعة ـ قال الأخفش:((خفيفة بلأنها من (أعْدرَوا)، وقال بعضهم : المعذّرون ثقيلة، يريد(المعتدرون)، ولكنه أدغخ التاء في الذال، كما قال: يَحَِّمؤن، وبها نقرأ)). (الأخفش، 1981 صفحة 335/2)، وينظر: (ابن غلبون، 1991 صفحة 442/2) و (ابن الجزري، 202/2 2002 صفحة ووقف الطبري على معنى " المعذرون " بالتخفيف وبالتشديد، وذكر أنَّ المعذَر في كلام العرب((إنّا هو الذي يعذر في الأمر فلا يبالغ فيه ولا يككم ، وليست هذه صفة 


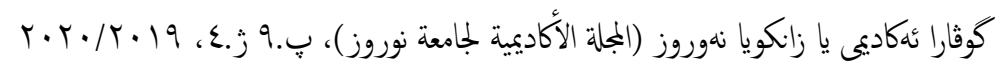

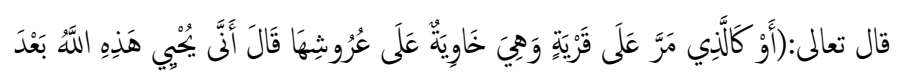

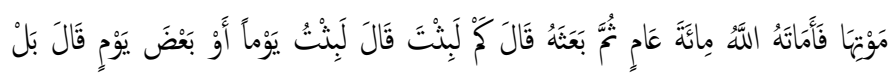

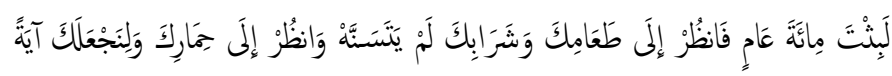

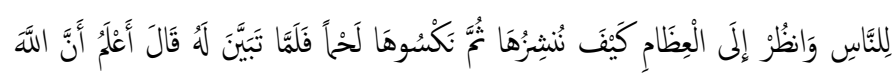
عَلَى كُلِّ شَيْيُ قَدِيرّ ) البقرة/259

قرأ الأخفش" أعَلُْ " بالرفع، وهي قراءة عامة قُرَّاء الأمصار. وقرأ حمزة والكسائي" اعَّمَّ " بوصل الألف وجزم الميم على الأمر. قال الأخفش:(( إذا عنى نسه، وقال

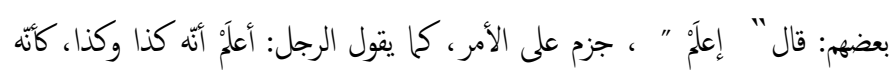
يقول ذلك لغيره، وإِنّا يُبنّه نفسَه، والجزم أجود في المعنى، إلاّ أنّه أقل في القراءة ، والرفع قراءة العامة وبها نقرأ)) (الأخفش، 1981 صفحة 183/1)، وينظر: (ابن مجاهد، 1972 صفحة 189) و (الأزهري، 1999 صفحة 86) . واختار الطبري قراءة الجزم على الأمر، وذلك لأنّ ما قبله أمر من الله سبحانه قولاً

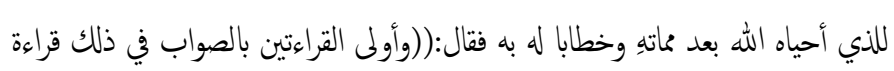
من قراً :" اعَلْه " بوصل الألف وجزم الميم على وجه الأمرمن الله تعالى ذكره للذي قد أحياه بعد مماتهِ بالأمر بأن يعلم أنّ الله الذي أراه بعينهِ ما أراه من عظيم قدرته وسلطانه من أحيائه إياه وحاره بعد موت مائة عام وبلائه حتى عادا كهينتها يوم قبض أرواحما ، وحفظ عليه طعامه وشرابه مائة عام حتى ردّه عليه كهينته يوم وضعه غير متغيرعلى مئل كل شيء قادر كذلك)). (الطبري، 2001 صفحة 66/3) وقراءة الرفع على وجه الخبر عن نقسه للمتكلم به بهمز ألف " أعلَمُ " وقطعها ورفح الميم، بمعنى : فلما تبيّن له من قدرة الله وعظيم سلطانه بمعاينته ما عاينه قال؛ أليس كذلك: أعلمُ الآن أنا أنّ الله على كل شيء قدير.

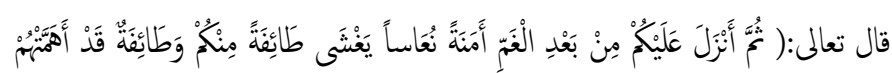

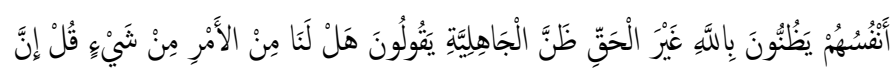

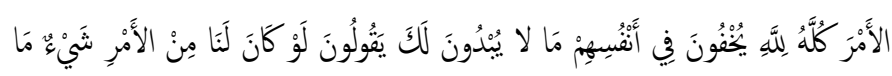

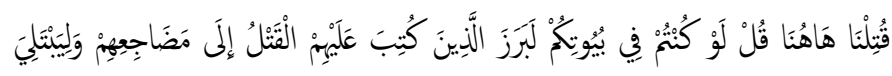

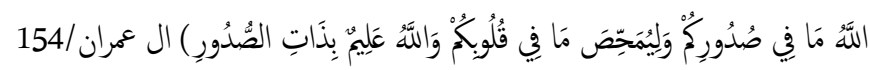
قرأ الأخفش" كلَّه " بالنصب، على التوكيد، وأجازعلى البدل من الأمر ، وعلى الصفة

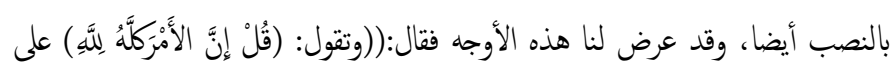

وجوّز الزجاج الكسر والفتح ، إلاّ أنَّ المصدر أحسن عنده ، وأوكد ؛لأنهّ يدل على توكيد الفعل. قال الزجاج: (ويقرأ: مرِها بكسر الراء - وزعً الأخفش إنَّ مرِها أجود من مرَها ؛ لأنَّ مرِها اسم فاعل- وهذا - أعني المصدر جيدٌ بالغ ، وكلاهـا في الجودة سواء ، غير إنَّ المصدر أوكد في الإستعمال ، تقول :جاء زيدُ رِكضا ، وجاء زيدُ راكضا"، فرِكاً أوكد في الإستعمال ؛ لأنَّ ركضاً يدل على توكيد الفعل ومَرهاً بنح الراء أكثر في القراءة)) . (الزجاج، 2004 صفحة 196/3)، وينظر: (الزخشري، د.ت. صفحة 667/2) و (ابن عادل، 1998 صفحة 286/12). أذن الاخفش وإن حسن الكسر ،لكنه قراء بالفتح ؛لأنَّ القراءة سنة متبعة. 3.2 المستوى النحوي

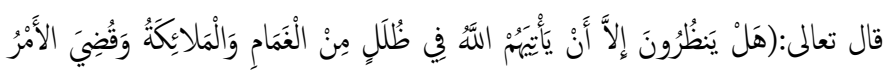

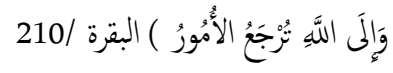

قرأ الأخفش" "الملايكةُ " بالرفع، وقد وصف الرفع بأنه الوجه على معنى : وتأتيهم الملانكةُ، فقال :((والملايكةُ، أي : وتأنيهم الملايكةُ، والرفُُ هو الوجه ، وبه نقرأ، لأنّه قد قال ذلك في غير مكان ، قال(وجاء ربك والملكُُ3) الفجر /22 ، وقال:( هَلْ يَنُرُونَ

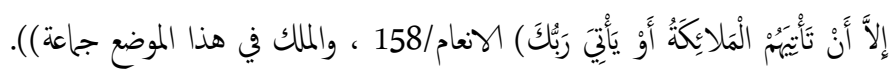
(الأخفش، 1981 صفحة 170/1)، وينظر: (ابن جني، 1386 هجري صفحة 122/1) و (القرطبي، 1988 صفحة 25/3) و (الالوسي، د.ت. صفحة 98/2)0 وهذه القراءة هي قراءة عبد الله بن مسعود والجمهور ـ قال الفراء:(رفٌّ مردود على الله تبارك وتعالى، وقد خفضها بعض أهل المدينة، يريد:"في ظلل من الغخام والملانكة " ، والرفعُ أجود ؛ لأنهّا في قراءة عبدالله (هل ينظرون إلاّ أن يأتيهم اللُهُ والملايكةُ في ظلل من الغام). (الفراء، 2001 صفحة 124/1)،على التقديم والتأخير ،أي:تقديم المعطوف عليه على الجار والمجرور · وقراءة الخفض هي قراءة أبي جعفر المدني والحسن البصري بالعطف على (ظُللَ)، أي :إلاّ أن يأنتهم في ظلل وِوفي الملايكة ،ويجوز أن يعطف على" الغام "أي:من الغام ومن الملانكة . وقد صوّب الطبري قراءة الرفع عطفاً بها على اسم الله تعالى على معنى: (هل

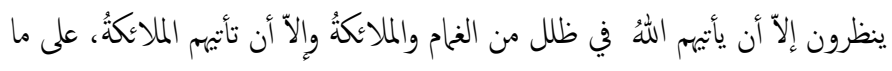
روي عن أبيّ بن كب)) (الطبري، 2001 الصفحات 446-447). 


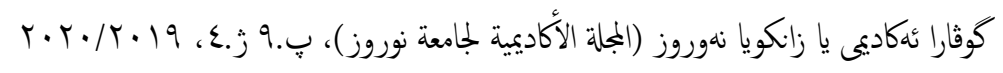

الأمصار، وبها يقرأ لإجاع الحجة عليها، وقد ذك عن الحسن البصري أنَّه كان يقرأ ذلك:(أو جاووم حِصرةً صُدُورُهُمُ) نصباً، وهي صحيحة في العربيّة فصيحة، غير أنّه غير جائز القراءة بها عندي لشذوذها وخروبجا عن قراءة قرّاء الإسلام)) . (الطبري، 2001 صفحة 270/4) 0ونقل النحاس قول الكسائي والمبرّد في توجيه المعنى فقال:((قال الكسائي : معنى (حَصِرَتُ) ضاقت،....... قال أبو العباس محمد بن يزيد: المعنى على الدعاء، أي: أحضرَالله صدورهم)). (النحاس، 2004 صفحة 232/1) 0وبيّن الأزهري توجيه الإعراب فيها واعتمد رأي البصريين في وقوع الفعل الماضي حالا فقال: ((حَصرَتْ : فعل ماض، والماضي لا يكون حالا إلاّ ؛ (قد)، أو أنّه خبر بعد خبر، كأنه قال: أو جاووك ثم أخبر فقال بعد (حصرت صدوره) أن يقاتلوك)). (الأزهري، 1999 صفحة 131) وينظر: (ابن إدريس، 2007 الصفحات 208/1-

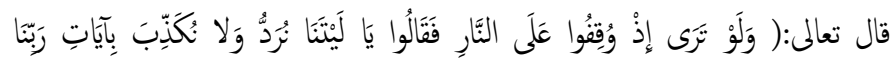
وَتَكُونَ مِنْ الْمُوْْمِنِنَ) الانعام/27

قرأ الأخشش" ونكونُ " بالرفع، ووصف قراءة الرفع بأهّا وجه الكلام بقوله: ((وإن شئت رفعت وجعلثه على مثل اليمين، كأنهم قالوا: ولا نكذّب والله بآيات ربّنا ونكونُ والله من المؤمنين ، هذا إذا كان ذا الوجه منقطعا من الأوّل، والرفع وجه الكلام، وبه نقرأ الآية)) (الأخفش، 1981 صفحة 273/2)، وينظر: (الطبري، 2001 صفحة 232/5) و (ابن الجزري، 2002 صفحة 257/2) ،وقراءة النصب بجعل الواو للعطف، فكأنهم قد تمنّوا أن يكذبّوا وأن يكونوا ،وقد جوّد الفرّاء قراءة الرفع على الإسئناف على معنى : فلسنا نكذّب أو بالعطف على الفعل" نُرّدُ "(الفراء، 2001 صفحة 276/1). ويبدو أنَّ سيبويه لمُ تُجبه قراءة النصب أيضاً بجعل الواو التي قبل"

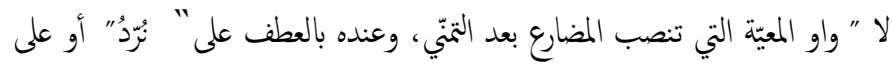
القطع والإستئناف أيضاً، أيّ: ونحن لا نكذب ونحن نكونُ ، يفهُم ذلك من قوله: دعني ولا أعودُ : أيّ : فإنيّ مُّن لا يعودُ ، فهو إسئناف ـ (سيبويه، 1968 صفحة

وذذك أنَّ أبا عمرو بن العلاء استدلّ على قراءة الرفع في الجميع بأنَّ قوله :(وأنّه لكاذبون) فيه دلالة على أنّم أخبروا بذلك عن أنفسهم، ولن يتمنّو؛ لأنَّ التمنيّ لا يقع فيه الكذب.وينظر: (القيسي، 1988 صفحة 249/1) و (الطبرسي، د.ت. صفحة
التوكيد أجود وبه نقرأ)). (الأخفش، 1981 صفحة 219/1). وقرأ ابو عمرو وحده" "كله "رفعا. والباقون نصبا. ينظر: (أبو زرعة، 1974 صفحة 177) و (الداني، 2005 صفحة 76) و (ابن عادل، 1998 صفحة 616/5)،وذكر ابن مجاهد أن أبا عمروقراً" رك

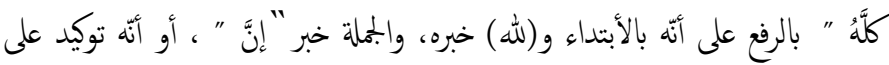
المحل، فإن اسمها - في الأصل - مرفوع بالابتداء ، وهذا مذهب الزجاج والجري يجرون التوابع كلها مجرى عطف النسق، فيكون الله خبرا لـ (إنَّ) أيضاً. (ابن مجاهد، 1972 صفحة 217) و (الفراء، 2001 صفحة 243/1) ،وصوّب الطبري قراءة النصب في" كلَّه " فقال:((والقراءة التي هي القراءة عندنا النصب في الكل لإجاع أكثر القّرّاء عليه من غير أن تكون القراءة الأخرى خطأ في معنى أو عربيّة. ولو كانت القراءة بالرفغ في ذلك مستفيضة في القّرّاء، لكانت سواء عندي القراءة بأيّ ذلك قريء لإتفاق معاني ذلك بأيّ وبحيه قريء)) ـ (الطبري، 2001 صفحة 191/3) . ووقف مكيّ القيسي على توجيهات الأخفش واختياره النصب في (كلة) لعلّة الأصل والإجلاع فقال:((ويجوز عند الأخفش أن يكون " كلَّه " بدلا من الأمر ، و(الله) الخبر في الوجهين ، والنصب الإختيار ،للإجاع عليه ولصحة وبحه، ولأنَّ التأكيد أصل" كل " لأنّها للإحاطة)) ـ (القيسي، 1981 صفحة 402/1)

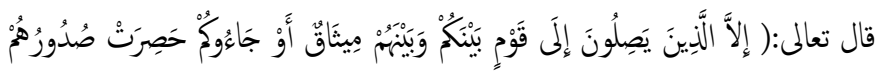

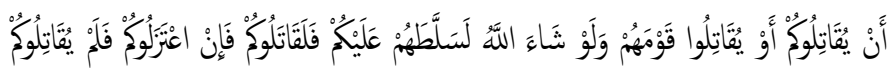

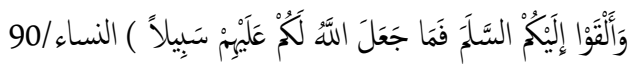

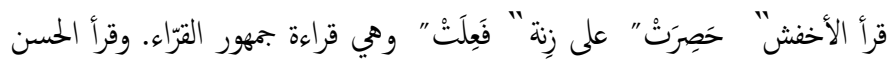
البصري ويعقوب والمفضّل عن عاصم" حَصِرَة " بنصب الاسم على الحاليّة. قال الأخفش:((أو(حَصِرتُ صدورُهم)؛ " حَصِرَةً " اسم نصبته على الحال، حَصِرَتُ: فَعِلَتُ، وبها نقرأ)). (الأخفش، 1981 صفحة 244/1)، وينظر: (القيسي، 1988 صفحة 205/1) و (أبو حيان، 1990 صفحة 317/3) و (السمين، 1994 صفحة 411/2 ووقف الفراء عند قراءة الحسن البصري وقتادة ويعقوب فقال:((وقد قرأ الحسن(حَصرةً صدورهم) والعرب تقول: أتاني ذهب عقله، يريدون قد ذهب عقلهُ). (الفراء، 2001 صفحة 282/1) وعلّق الطبري على قراءة الحسن ووصفها بالشذوذ لخروبحا عن الإجحاع فقال:((وعلى هذه القراءة ، أعني:" حَصرَتْ" قرأ القرّاء في جميع 


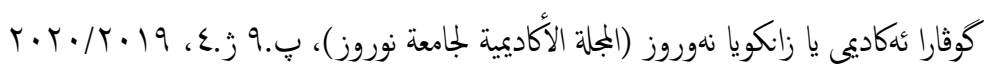

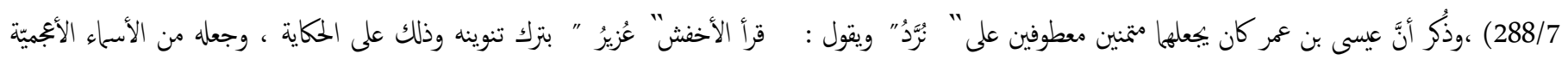

التي لا تنصرف. وترك التنوين قراءة جمهورالقرّاء سوى عاصم والكسائي ، إذ قرءا

أنَّ الله أكذهم في تمنيهم على قول من يرى التمنيّ 0

بالتنوين ، وروي عن أبي عمرو أنّه قرأ بالتنوين أيضاً. (ابن مجاهد، 1972 صفحة

313) و (ابن خالويه، 1999 صفحة 174) و (القرطبي، 1988 صفحة 116/8)

0قال الأخفش: ((وقد طرح بعضهم التنوين ، وذلك رديء ، لأنهّ إنّا يترك التنوين إذا

كان الاسم يستغني عن (الابن) ، وكان ينسب إلى اسم معروف، فالاسم هاهنا لا

يستغني ، ولو قلت:(وقالت اليهود عُزيزُ) ، لم يتمّ كلاما إلاّ أنّه قد قُرئ وكثر ، وبه نقرأ على الحكلية، كأنهم أرادوا: وقالت اليهود نبينّا غُريُر بن الله)). (الأخفش، 1981 صفحة

$0(329 / 2$

وذكر سيبويه أنّ القياس ثبوت التنوين. (سيبويه، 1968 صفحة 540/3) ،ومذهب

الفرّاء في تنوين "عُيرّ " وهي قراءة عاصم والكسائي. قال أبو منصور: ((وقال الفزّاء : الوجه التنوين لأنّ الكلام ناقص، و(ابن) موضع الخبر لـ (غُرير) فوجه العمل في ذلك تونك تُنوّن ما رأيت من الكلام محتاجاً إلى (ابن) فإذا اكنفى دون (ابن) ، فوجه الكلام أن لا تُوّن، ، وذلك مع ظهور اسم أب الرجل أو كنيته، فإذا جاوزت ذلك أضفت (ابن)

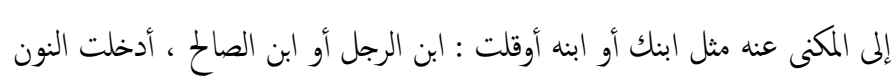
في التام منه والناقص، وذلك أنَّ الحذف في النون إنمّاكان في الموضع الذي يجري في الكلام كثيرا ، فيستخِّ طرحما في الموضع المستعمل ، وقد ترى الرجل يذكر بالنسب إلى أبيه كثيرا، فيقال: من فلان بن فلان إلى فلان، فلا يجري كثيرا بغير ذلك ، وربّمّا حُذفت النون وإن لم يتمّ الكلام ، لسكون الباء من (ابن) ، فيستثقل النون إذاكانت ساكنة لقيت الكلام ، فذذفت استثقالا لتحريكها، من ذلك قراءة الفراء (عُريُ ابنُ الله) بغيرتنوين)). (الفراء، 2001 صفحة 206)

واختار الطبري والنحاس التنوين، إذ وصف بالجودة والفصاحة. قال الطبري: (والصواب عندنا في ذلك التنوين لمعنيين. أحدها : أفصح اللغتين وأشهر الكلامين، وأجودها عند العرب. والثاني : إجلاع الحجّة من قراء الأمصار على اختيار التنوين فيه، ففي ذلك يكتفي عن الإستشهاد على صحة غيره)). (الطبري، 2001 صفحة 321/17)، وينظر: (النحاس، 2004 صفحة 37/2)، (الزخشري، د.ت. صفحة وخلاصة القول:إنَّ(نكذب،ونكون) تقرآن بنصب الباءوالنون ورفعها، فالنصب على أنَّه جواب (ليت)بالواو، لانَّ التمني بمنزلة الأمروالنهي في أنَّ الجواب بالنصب ،والرفع على الإستئناف ،أي نحن لانكذب ونحن نكون ،أويكون عطفا على (نردُ) والتقدير: ياليتنا

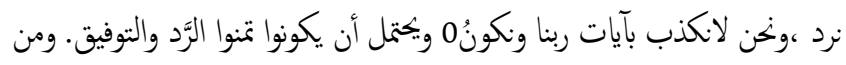
التوفيق ترك الكذب0 ينظر: (ابن خالويه، 1999 صفحة 392) و (الباقولي، 1971 صفحة 543/1)

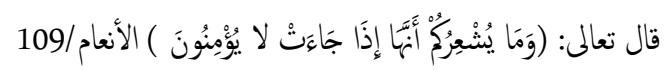

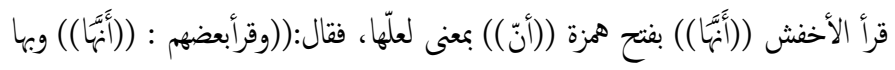
نقرأ ، وفنّر على(( لعلّها)) ، كما تقول العرب: إذهبْ إلى السوق أنك تشتري لي شيئا، أي: لعلك. (الأخفش، 1981 صفحة 285/2)، وينظر: (الطبري، 2001 صفحة 398/5)، (النحاس، 2004 صفحة 347/1) ،والقراءة بفتح هزه ((أنّ))هي قراءة عامة القراء سوى ابن كثير وأبيّ عمرو وأبي بكر ويعقوب، وهي بالفتح بمعنى ((لعلّ))والتقدير: لعلّها إذا جاءت لايؤمنون. وقد يكون التقدير بجيء ((أنّ)) على أصل الباب وتكون ((لا)) زائدة، والمعنى :(وما يشعرى أنّها إذا جاءت يؤمنون)، فهي((أنّ)) الشديدة الواقعة بعد الأفعال التي بمعنى الثبات ، والتقدير نحو:((علمثُ، تبينتُ، تيقنتُ)، أي:أنّها لو جاءت لم يؤمنوا، وإنّ جاءتهم الآية التي إقترحوها، (سيبويه، 1968 صفحة 123/3) ،وينظر: (القيسي، 1988 صفحة 265/1) 0 ونقل الطبري ما جاء به الأخفش من أنهّا بمعنى ((لعلّ)) ومثّل بقول العرب ويقول عدي بن زيد ودريد بن الصمّة. والقراءة بفتح الألف من ((أنّ)) هي قراءة عامّة قراء أهل المدينة والكوفة ، (الطبري، 2001 صفحة 409/5) ، وينظر: (الأزهري، 1999 صفحة 165) والقراءة بكسر هزة (إنّ) على معنى الإبتداء ، إخبار بعدم إيمان من طبّع على قلبه ، ولو جاءتهم كلّ آية. والقراءة بالفتح بحمع عليها ، وهي قراءة عامَّة القُرّاء. ينظر: (أبو مريم، 2009 صفحة 310)

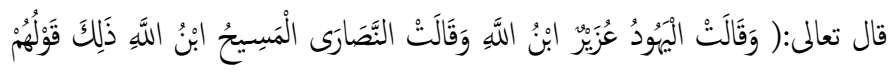

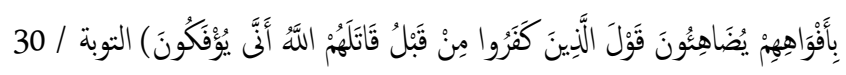




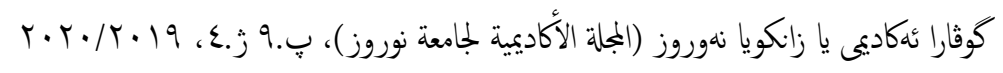

مَنْ قرأ "إنّه عَملّ غيرُ صاح " يرجّح كون الضمير يعود على نداء نوح المتضمّن السؤال. قال صاحب اللُباب :((قوله:( إنّه عَملّ غيرُ صاح) : قرأ الكسائي (عملَ) فعلا ماضياً. و (غيرَ) نصباً. والباقون (عَمله) بفتح الميم وتنوينه على أنّه اسم و(غيرُ) بالرفع. فقراءة الكسائي: الضمير فيها يتعينُ عوده على ابن نوح، وفاعل (عمِلَ) ضمير يعود عليه أيضاً،

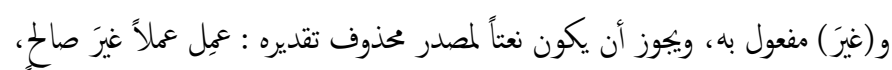
كقوله (وأعملوا صالحاً) المؤمنون/51 ، وقيل : إنّه ذو عمل باطل، فحذف المضاف لدلالة الكلام عليه)). (ابن عادل، 1998 الصفحات 500/10-501)،وينظر: (الزخشري،

$$
\text { د.ت. صفحة 399/2) و (البيضاوي، } 1998 \text { صفحة 136/3). }
$$

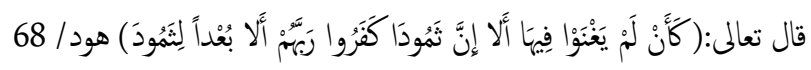
قرأ الأخفش" ثموداً "هنا بالتنوين والصرف ، وذلك لأنَّ رسم المصحف كُبت بالألف ، وعلل الصرف والمنع فيها فقال :((كتاها بالألف في المصحف، وإنّا صرفت ؛لأنّه جعل (ثمدَ)|سم الحيّ أو اسم أبيه، ومن لم يصرف جعله اسم القبيلة، وقد قرئ هذا غير مصروف، وإنّا قرئ منه مصروفا ماكانت فيه الألف، وبذلك نقرأ. وقد يجوز هذا كلّه في جميع القرآن الكريم؛ لأنه إذا كان اسم الحيّ أو الأب ، فهو اسم مذكر ينبني أن يُضْرَف)). (الأخفش، 1981 صفحة 355/2)،وينظر: (الفراء، 1999 صفحة 20/2) و (أبو زرعة، 1974 صفحة 344) و (ابن سوار، 2005 صفحة 102)و (القيسي،

1981 صفحة 533/1).

وصرّح الأزهري بوجوب إتباع مذهب القراء في صرف" ثمود " أو عدم صرفه، ف (ثمود ) ورد بالوجينين في القران الكريم، وقرأه حزة وحفص وييى، والحضري غير مجري، وأجراه الباقون. قال أبو منصور:((مَن لم يُوَّن (ثمود) ذهب بها إلى القبيلة فترك

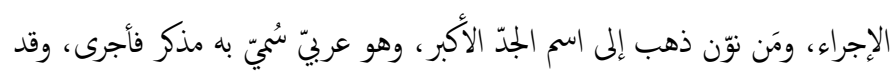
جاء في القرآن مجرى وغير مجرى. والمواضع التي إتّق القراء على تركك إجرائه ينبغي أن تُقرأ كما قرؤوا، وما اختلفوا فيه، فإليك الإختيار )). (الأزهري، 1999 صفحة 256). وثمود اسم عربيّ على وزن فَعُولْ من الثّمد ،و (الثّمدُ والثّمَدُ): الماء القليل الذي لامدد

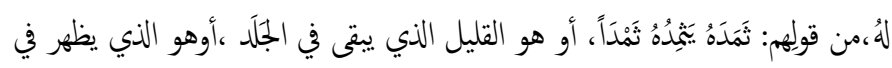
الشتاء ويذهب في الصيف والجمع أثمَّد.. (ابن منظور، 2004 صفحة 37/3) ،ومن قرأه غير مصروف جعله اسم قبيلة، فاجتمعت فيه علّّان: التأنيث والتعريف، ومن قراً ( ثمودا ) منونا صرفه على أنّه اسم رجل أو حيّ .ينظر: (المبرد، 1963 صفحة 353/3)

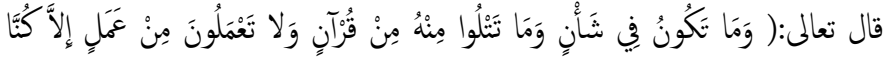

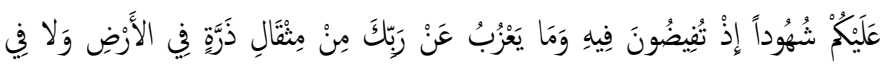

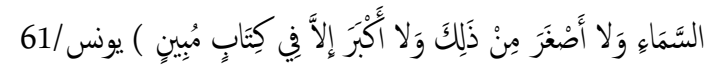
قرأ الأخفش بفتح الراء في" أصغَر " ، وفي" أكَرَ" على تقدير حرف الجر" من" ومنعها من الصرف، فقال: (أيّ: ولا من أصغَر ذلك ولا من أكبرَ، ولكنه(أفعَل) ولا ينصرف، وهذا أجود في العربيّة والأكثر في القراءة، وبه نقرا)). (الأخفش، 1981 صفحة 346/2)، وينظر: (ابن بجاهد، 1972 صفحة 328) و (ابن سوار، 2005 صفحة 193/2) و (ابن عادل، 1998 صفحة 364/10) ووقف الفزّاء على القراءتين فقال: ((فن نصبها فإنِّا يريد الخفض، يتبعها المثقال أو الذزّة، ومن رفعها أتبعها معنى المثقال ، لأنك لو ألقيت من المثقال "مِنْ "كان رفعاً )). (الفراء، 2001 صفحة 470/1) ،وقد قرأ مزة وخلف ويعقوب برفع الراء فيها على لى تقدير: ولا تعزب عنه أصغرُ من ذلك ولا أكبرُ، عطفاً على معنى المثقال لأنَّ معناه الرفع. وصوّب الطبري قراءة الفتح على وجه الخفض، فقال: (وأولى القراءتين في ذلك بالصواب قراءة من قرأ بالفتح على وجه الخفض، والردّ على الذرّة، لأنَّ ذلك قراءة قُرّاء الأمصار، وعليه عوام القّراء ، وهو أصحّ في العربيّة مخرجا، وإن كان للأخرى وجه معروف)). (الطبري، 2001 صفحة 169/7)

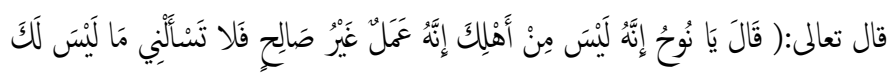

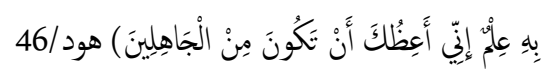
قرأ الأخفش "عَمِلَ غيرَ " فعلا ماضياً يعود على ابن نوح ونصب غيرَ على المفعولية. قال الأخفش: ((منّون، لأنّه حين قال: والله أعلم: (لا تسألني ما ليس لك به علم) كان في معنى (أنْ تَسألني)، فقال: إنّه عَملّ غيرُ صالح، فلا تسألني ما ليس لك به علم. وقال بعضهم :( عَمِلَ غَيرَ صاح ) وبه نقرأ)). (الأخفش، 1981 صفحة 353/2)، وينظر: (الفراء، 1999 صفحة 17/2) و (ابن خالويه، 1999 صفحة 106) و (الفارسي، 2001 صفحة 399/2).

والقراءة بجعله فعلاً ماضياً ونصب "غيرَ " هي قراءة عليّ بن أبي طالب(رضي الله عنه) وأنس وابن عباس وعائشة، وروتها عائشة وأم سلمة عن النبيّ صلوات الله عليه، وهذا يرجّح أنَّ الضمير يعود على ابن نوح ينظر: (الفراء، 1999 صفحة 17/2) و (الطبري، 2001 صفحة 32/12) و (ابن الجزري، 217/2) ،وقراءة 2002 صفحة 


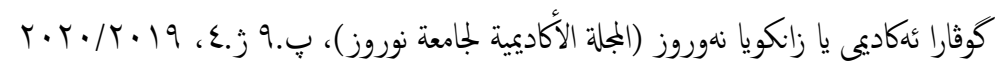

رضي الله عنه.وبها قرأ السبعة . ينظر:(القيسي، 1988 صفحة 357/2) ،قال الأخفش:((وقال بعضهم; (عُُْراً) خفيفة، أو (نُّرا) مثقلة ، وهي كثيرة وبها نقرأ)). (الأخفش، 1981 صفحة 103/1)،وينظر: (الفراء، 1999 صفحة 222/3) و (ابن مجاهد، 1972 صفحة 666) و (ابن خالويه، 1999 صفحة 236) و (ابن عطية، 1974 صفحة 417/5) و (أبو حيان، 1990 صفحة 396/8)، والسكون والضمّ فيها أنّه يجوز أن يكون كلّ منها أصلاً للآخر، وأن يكونا أصلين، ويجوز في كل من المثقل والمخفف أن يكون مصدراً وأن يكون بمعاً سُكِنّت عينه تخفيفاً. قال الزجاج:(وقُرَت

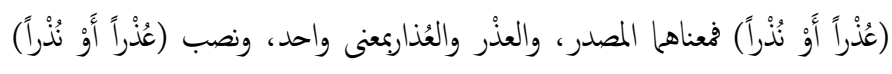
على ضربين: أحدها: مغوول على البدل من قوله:(ذكراً) المعنى: فالملقيات عذرا أو نذرا،

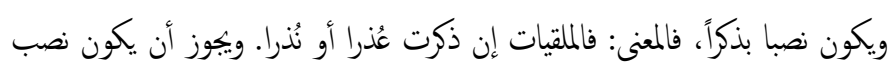
(عُُْراً أَوْ نُذْراً) على المفعول له، فيكون المعنى : فالملقيات ذكراً للأعذار والإنذار)). (الزجاج، 2004 صفحة 208/5)وينظر: (ابن إدريس، 2007 صفحة 939/2).

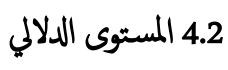

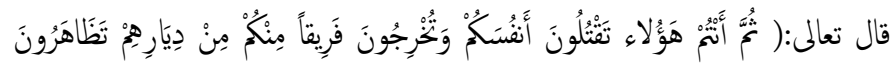

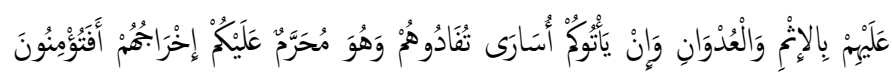

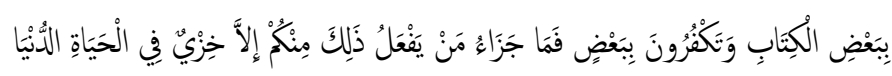

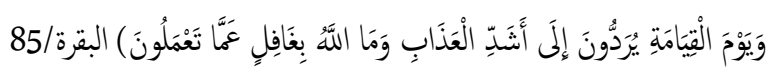
قرأ الأخفش" تُفادوه" مبالألف زنة "فاعَلَ "وهي قراءة نافع وعاصم والكسائي، وقراً غير هؤلاء" تفدوهم" بغيرألف زنة" فعَلَ" ـ قال الأخفش:((وقال بعضهم:(تفُوهُم) من (تَفدي)، وبعضهم (تُفادوهم) من فادى يُفادي، وبها نقرأ، وكلّ ذلك صواب)). (الأخفش، 1981 الصفحات 128/1-129). وينظر: (الأزهري، 1999 صفحة 56)، (ابن مجاهد، 1972 صفحة 164)، (الرعييني، 2000 صفحة 80)، (القرطبي، 1988

صفحة 59).

والفداء على وبحين : أحدها تفدوهم بالمال. والآخر: أن يكون معنى فديته خلّصته مما كان فيه، ومعنى تفدوه تشترونهم وتنقذونه، ومعنى(تفادوهم) تماكسون من هم في أيدهه بالثمن ويُكسكونك. وقد فصّل الطبري القول فيا جاء في الآية من القراءات ووقف على معنى (تفادوهم) بقوله : (وأمّا مَنْ قرأ (تفادوهم) فإنّه أراد أنكم تفدونهم من

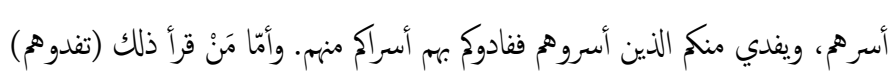

و (ابن عطية، 1974 صفحة 187/3) (ابن منظور، 2004 صفحة 37/3)و (أبو حيان، 1990 صفحة 241/5) و (السمين، 1994 صفحة 111/4).

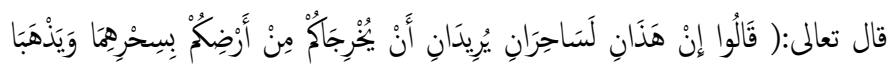

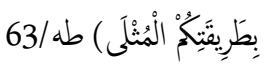

قرأ الأخفش" إنَّ " مثقلة، وجعل الخففة في معنى الثقيلة، فقال:((خفيفة في معنى الثقيلة، وهي لغة قوم يرفعون ، ويدخلون اللام ليفرقوا بينها وبين التي تكون في معنى (ما) ونقرأها ثقيلة، وهي لغة لبني الحارث بن ككب)). (الأخفش، 1981 صفحة 408/2).قرأ نافع وابن عامر وحمزة والكسائي (إنّ) مشدّدة النون (هذانِ) بألف خيفة النون. ينظر: (ابن مجاهد، 1972 صفحة 419) و (ابن سوار، 2005 صفحة 290/2) و (القيسي، 1981 صفحة 99/2). وقرأ الفرّاء بتشديد" إنَّ " وبالألف" هذان" وقد اعتَّد برسم المصحف الشريف وعلّل وجه القراءة عنده بأنّها على لغة بني الحارث بن كعب، والوجه الآخر أنّه وجد الألف من هذا دعامة ، وليست بلام الفعل، فلّما ثُنيت زدت عليها نوناً ثم تزكت الألف ثابتة على حالها لا تزول على كل حال، كما قالت العرب "الذي "ثم زادوا نونا تدل على الجماع، فقالوا: الذين في رفعهم ونصبه وخفضهم كما، تركا" هذان" في رفعه ونصبه وخفضه. (الفراء، 1999 الصفحات 183/2-184)،وينظر: (النحاس، 2004 صفحة 323/2) و (القرطبي، 1988 صفحة 216/11) وصوّب الطبري تشديد النون وبالألف في" هذان" لعلّة الإجاع، والرسم المصحني، فقال:((والصواب من القراءة في ذلك عندنا;" إنَّ " بتشديد نونها وهذان بالألف لإججاع الحجّة من القراء عليه، وأَنّ كذلك هو في خط المصحف، ووبحه إذا قُرئ كذلك مشاهته" " الذين " إذا زادوا على الذي النون · وأقرّ في جميع الأحوال الإعراب على حالة واحدة، فكذلك (أنَّ هذان) زيدت على هذا نون ، وأقرّ في جميع أحوال الإعراب على حالة واحدة، وهي لغة بني الحارث بن كقب وخثم وزبيد ومن وليهم من قبائل اليمن)). (الطبري، 2001 صفحة 227/9) قال تعالى:( عُذْرَا أَوْ نُنْراً) المرسلات

قرأ الأخفش" عذرا " و"نذرا "بسكون الذال الأوّلى مخفقة، وضمّ الذال الثانية مثقلة، وهي قراءة الحرميين(ابن كثير المكي ونافع المدني) ،وابن عامر وعاصم في رواية أبي بكر 


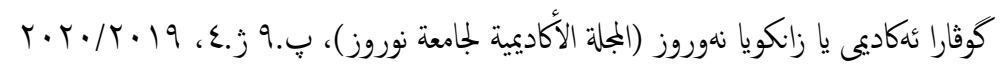

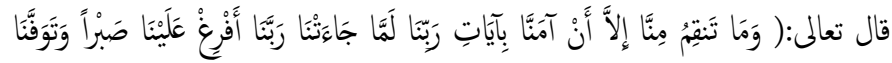
مُسْلِمِنَ) الاعراف/126 قرأ الأخفش" تَنْْمِ " بكسر القاف مضارع" نَّمَّم " بنتح القاف في الماضي. قال

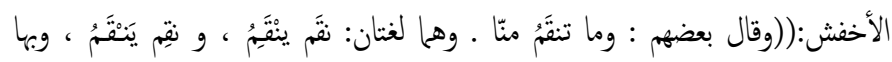
نقرأ، أيّ بالأوّل)). (الأخفش، 1981 صفحة 308/2) ،وقراءة الأخفش هي قراءة جمهور القّرّاء وهي اللغة الفصيحة. قال أبو حيان:((قرأ الحسن وآخرون: وما تنقَم بفتح القاف، مضارع نقيم، بكسرها، وها لغتان والأفصح قراءة الجمهور)). (أبو حيان، 1990

صفحة 366/4).

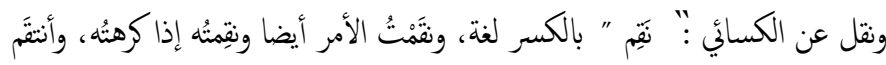

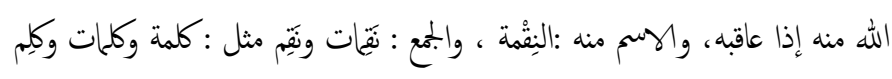
، إن شئت سكنّت القاف ونقلت حركها إلى النون فقلت : نِقْمة والجمع : ينَّمَ ، مثل: رِنْمة وِنعَمْ · ينظر: (القرطبي، 1988 صفحة 151/6)، (ابن عادل، 1998 صفحة

.$(403 / 7$

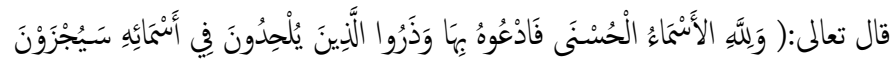
مَاكَنُوا يَعْمَلُونَ عالاعراف / 180

قرأ الأخفش" يُلْحِدوُن " بضّ الياء وكسر الحاء مضارع ألحد الرباعي، وهي قراءة جمهور القرّاء ، وقد وصفها بالككرة فقال:((وقال بعضهم : يَلْحَدوُن ، جعله من لحدَ يَلْحَد، وهي لغة. وقال في موضع آخر:(لسانُ الذي يُلِْدون) النحل/103 ، وهما لغتان، يُلْحِدون أكثرُ ، وبها نقرأ، ويقوّها: (ومَنْ يرُد فيه بالحاد بظلم) الحج/25 )). (الأخفش، 1981 صفحة 315/2). قرأ ابن كثير ونافع وابن عامر وعاصم وأبو عمرو (يُلْجِدون) بضمّ الياء . ينظر: (ابن مجاهد، 1972 صفحة 298) و (ابن خلويه، 1999 صفحة 92) و (القرطبي، 1988 صفحة 101) و (ابن غلبون، 1991 صفحة 429/2). وبيّن الأزهري معنى" يُلْحِدون " ومعنى " يَلْحَدون " ونقل قول الفرّاء فيمن ضمّ الياء على أنّه يعترضون، ومن فتح الياء أراد : يميلون ونقل رواية أبي عبيد عن الأمرر: لحدنتُ : جُرتُ ومِلْتُ. وألحدنُ : ماريت وجادلتُ. قال أبو منصور: (وأصل اللحد والإلحاد: الجور عن القصد وأخرني المنذري عن الحراني عن ابن السكيت قال: المُحْد: العادل عن الحق المدخل فيه ما ليس منه. يقال: ألحد في الدين
فإنهن أراد أنكم يا معشر اليهود إن أنتاك الذين أخرجتموهم منكم من ديار هم أسرى فديتموهم فاستنقتموهم ، وهذه القراءة أججب إليَّ من الأوّلى أعني : (أسرى تفدوهم )؛لأنّ الذي

على الهيود في دينهم فداء أسراهم بكل حال، فدى الآسرون أسراهم منهم أح لم يفدوه)). (الطبري، 2001 صفحة 564/1) وفسّر ابن خلويه معنى الفداء ومعنى الأسر في الآية ووجّه القرائتين فيها فقال:(وجعل (تفادوهم) فعلاً من إثنين ؛ لأنّ الفداء : أن تأخذ ما عنده وتعطي ما عندك، فنفعل به كما يفعل بك)). (ابن خالويه،

1999 صفحة 34)

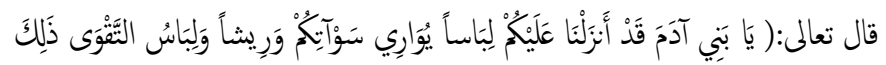

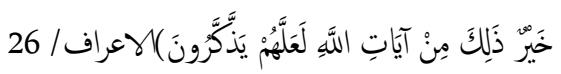
قرأ الأخفش" وريْشَا " وهي قراءة جمهور السبعة، وروي أبان والمفضل والحسن البصري " ورياشا " بألف. قال الأخفش:(وقراً بعضهم (ورِيْشا) وبها نقرأ، وكلٌّ حسنٌ ومعناه واحدّ)). (الأخفش، 1981 صفحة 297/2) وفي معنى الريش قولان أحدها : أنّه اسم لهذا الشي المعروف. والآخر: أنّه مصدر يُّال : راشه يريشه ريشا ، إذا جعل فيه الريش، فهو مشترك بين المصدر والعين.

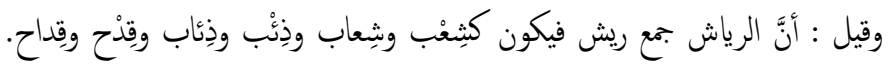
وقد يكون مصدرا أيضا، فيكون ريش ورياش مصدرين لـ" راشَه الله ريشا و رياشا "بععى : أنعم عليه. وقال الزجاج:((ه) اللباسُ، فعلى هذا ها اسمان للشيء الملبوس، كما قالوا: لِبْسُ ولباسُ)). (الزجاج، 2004 صفحة 362/2). وينظر: (الفراء، 1999 صفحة 375/1)، (النحاس، 2004 صفحة 377/1)، (ابن خالويه، 1943 صفحة 43) ،وقيل : وريشا يعني مالا، يقال: تريّش الرجل إذا تموّل. ونقل الأزهري قول الفراء فقال: فإن شئت جعلت الرياش جمع الريش، وإنّ شئته مصدرا في معنى الريش، كما قالوا: لِبُِّ ولباسُ. قال أبومنصور:((القراءة (وريشا) لا غير )). (الأزهري، 1999 صفحة 177). وينظر: (الزخشري، د.ت. صفحة 97/2) و (ابن عطية، 1974 صفحة 389/2) و (أبو حيان، 1990 صفحة 283/4) ،وهو قول الطبري وذلك لإجحاع الحجّة من القّراء عليها. وفسّر ابن جنيّ معنى الرياش بقوله :(يكتل

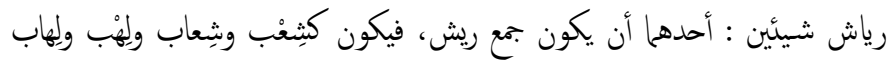

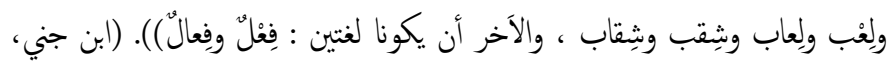
1386 هجري صفحة 246/1) 


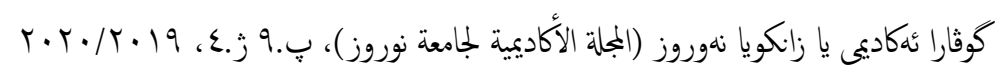

صاحب اللباب القول في القرائين فقال: ((وقرأ مزة والكسائي - هنا - وفي الأنفال - يُميّز - بالتشديد، والباقون بالتخفيف، وعن ابن كثير - أيضاً يُيْزمن "أماز " فهذه ثلاث لغات، يقال: مَازه وميّزه وأمازه ـ والتشديد والممزة ليسا للنقل، لأنّ الفعل -

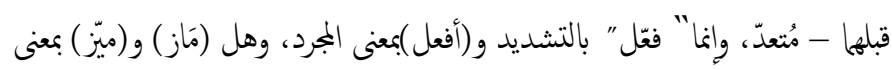
واحد، أو بمعنيين مختلفين ؟ قولان · ثم القائلون بالفرق اختلفوا، فقال بعضهم : لا يُّال:

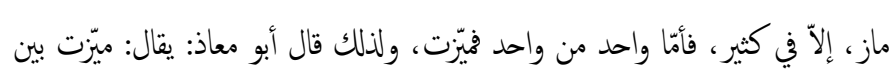

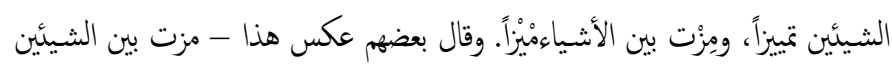
مَيْزا، وميّزت بين الأشياء تمييزاً وهذا هو القياس، فِإنَّ التضعيف يؤذن بالتكثير ، وهو لائق بالمتعددات، وكذلك إذا جعلت الواحد شيئين قلت: فرَقت - بالتخفيف ومنه : فرَق الشعر، وإن جعلته أثشياء قلت: فرَّقها تفريقاً. ورجّح بعضهم" مَيّز" بالتشديد، بأنه أكثر إستعالاً، ولذلك لم يستعملوا المصدر إلاّ منه، قالوا : التمييز، ولم يقولوا: المَيْز ، يعني لم يقولوه سماعاً، والاّل فهو جائز قياساً )). (ابن عادل، 1998 صفحة

.$(80 / 6$

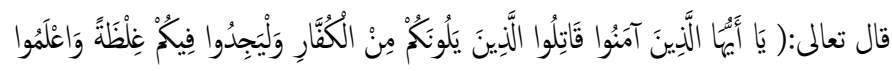

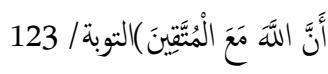
قرأ الأخفش" غِلظة " بكسرالغين، وهي قراءة جمهور القرّاء، وقُرِتْ أيضاً بضمّها وبفتحها. قال الأخفش: ((وبها نقرأ، وقال بعضهم: (غُلظة) وها لغتان)). (الأخفش، 1981 صفحة 339/2) والغلظة - هنا --إنا تعتبر فيما يتعلق بالدعوة إلى الدين، وقد

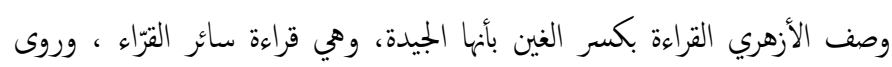
المفضّل عن عاصم" غَلظة " بنتح الغين ـ قال أبو منصور: ((هلا لغتان: غِلظة وغَظةة ، وأجودها الكسر، وفيه لغة ثالثة لم يقرأ بها" غُُظة " بالضمّ ، فلا تقرأ بها)). (الأزهري، 1999 صفحة 218)، وينظر: (ابن مجاهد، 1972 صفحة 320) و (ابن خالويه، 1999 صفحة 100) و (البيضاوي، 1998 صفحة 102/3) و (الزخشري،

د.ت. صفحة 324/2).

وذهب الطبرسي إلى أنَّ أوجه القراءات الثلاث هي لغات، لكنّ الكسر قراءة الناس ، وهي العربيّة، وهو رأي الزجاج أيضاً. ينظر: (الطبرسي، د.ت. صفحة 83/5)، (الزجاج، 2004 صفحة 385/2)، (السمين، 1994 صفحة 513/3). وفصّل صاحب اللباب القول في هذه القراءات فقال: ((فِلظة : قرأ الجمهور بكسر الغين، وهي
ولحد عن الحتق: إذا مال وعدَل ، واللّحد: الشق في جانب القبر، مأخوذ منه، وقد ألحت للميت لحداً، ولحدت بمعناه)). (الفراو، 2001 صفحة 194). وفرّق الكسائي بين لحد وألحد فقال: ((لحد وألحد هما لغتان. وذكر عن الكسائي أنّه كان يفرّق بين الإلحاد واللحد، فيقول في الإلحاد أنّه العدول عن القصد، وفي اللحد أنّه الرون إلى الثيء)). (الكسائي، 1998 صفحة 149). وبيّن الطبري أنَّ أصل الإلحاد في كلام العرب العدول عن القصد والجورعنه والإعراض، ثم يستعمل في كلّ معوج غير مستقيم، ولذلك قيل للحد القبرلحد؛ لأنهّ في ناحية منه وليس في وسطه. يقال منه ألحد فلان يُلحد إلحاداً، ولحدَ يلحد لحداً ولحوداً، وقد ذُكِرعن الكسائي أنّه كان يفرّق بين الإلحاد واللحد، فيقول في الإلحاد أنّه العدول عن القصد ، وفي اللحد إنّه الرون إلى الشي” ، وقد اختار الطبري القراءة" يُلْدِدون " بضم الياء وكسر الحاء فقال: ((والصواب من القول في ذلك إنها لغتان بمعى واحد، فبأيتها قرأ القارى" فصيب في ذلك، غير أني أختار القراءة بضمّ الياء على لغة من قال ألحد، لأنهّا أشهر اللغنتن وأفصَحها)) (الطبري، 2001 الصفحات 91/9-92)، وينظر: (ابن إدريس، 2007 الصفحات 334/1) ) ، (البيضاوي، 1998 صفحة 43/3).

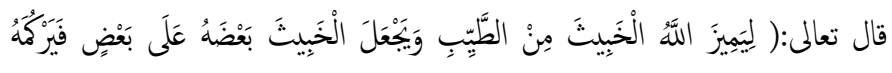

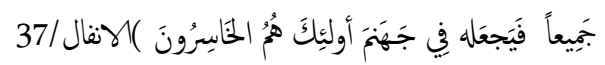
قرأ الأخفش" لِيَميزْ " بالتخفيف، وهي قراءة السبعة سوى حمزة والكسائي، فالقراءة عندها بالتشديد" لِيُميّز " بضم الياء وفنح الميم وكسر الياء مشدّدا. قال الأخفش:

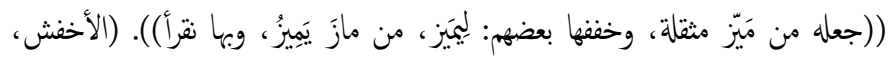
1981 صفحة 322/2). وينظر: (ابن مجاهد، 1972 صفحة 306) والمعنى حتى يميز الله المنافق من المخلص المؤمن فالله سبحانه وتعالى يمتحن الناس ويميزم ـ قال أبو منصور: (ايقّال: مَيّزت الشيء من الشيء فتَميّز ، إذا خلّصته منه، والمعنى : أنّ المؤمن هو الطيب وميزه الله من الخبيث، وهي المشركون، أي: خلّصهم، ومن قرأ(حتى يَيميز)

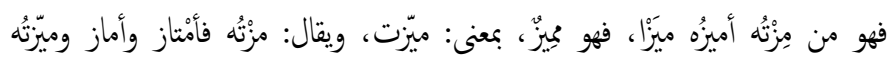
فنميّز)). (الأزهري، 1999 الصفحات 114-115). وعرض أبو على الفارسي للقرائتين فقال: ((وكلنا القرائتين حسنة؛ لأنَّ مازَ فعل متعدّ إلى مفعول واحد، كما أنّ ميّز كذلك، ولقولم ماز من المزيّة أن أكثر القراء عليها، وكثرة

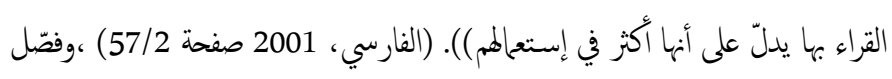




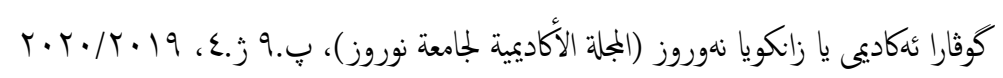

لغة أسد، وقرأ الأعش وأبان بن تغلب والمفضّل كلاهما عن عاصم بفتحها، وهي لغة 3. خاتمة البحث الحجاز، وقرأ أبو حيوة والسُلميّ وابن أبي عبلة والمفضّل وأبان في رواية عنها غُلظة وققنا عند القراءة التي إختارها الأخفش في كتابه معاني القرآن وقراً بها ونسجل هذه بالضمّ، وهي لغة تيم، وحكى أبو عمرو اللغات الثلاث ـ والغِلظة : أصلها في الإجرام الاشارات التي وردت عنه ، فنقول:

إنّه اعتمد قراءة عامة قرّاء الأمصار مع إعتافه أحيانا بأنَّ القراءة الثانية أجود في المعنى، فهو كثيرا ما يختار قراءة الجمهور ويعتمدها في القراءة والإختيار استشهد الأخفش بالنص القرآني في ترجيح القراءة التي يختارها، وقد وردت عنه عبارات في معانيه تؤكد ذلك منها قوله : (( ويقوّها)) وقوله :((وقال في موضع آخر )) ، ويستشهد بالنصوص القرآنية. اعتدّ برسم المصحف الشريف في توجيه القراءة واختيارها، وقد جاء ذلك بقوله : ((كتانها بالألف في المصحف)) ، وقد يخرج أحيانا في اختياره عن رسم المصحف الثريف، ومن ذلك قوله : ((عزير )) بترك التنوين وذلك على الحكلية، وجعله من الاسماء الأججمية ،وهي قراءة جمهور القراء ، وقراءته ((إنّه عملَ غيرَ صالح) (ملى الفعليّة. وقف عند لغات القبائل في ضبط البنية وتوجيه القراهة ، وقد ورد ذلك عنه في قوله: وهي لغة لبني الحارث بن كقب. استشهد بكلام العرب وأقوالهم في الدلالة على ترجيح القراءة المعتبرة عنده في

$$
\text { قوله: ((وهي أكثر في كلام العرب)) وقوله: ((لأنّ العرب تقول)). }
$$

وردت عنده عبارات توحي بقدرته على بيان المعنى واللدلالة لآيات الكتاب العزيز منها قوله: (لألهّا أوفق للكناب)) وقوله: ((لأنّه قد قال ذلك في غير .) (l)

للعلّة وأدلة الصناعة نصيبٌ في توجيه القراءة عنده، فلّه عبارات توسم ذلك الأمر وهذه المزبّة منها علّة الكثرة ،وعلّة الجودة ،وعلّة الإستحسان ،وعلّة الإجاع ، إذ اعتمد علّة الجودة والكثرة مقياسا في إختياراته ، وعلّة الإجحاع لها مكان عنده في

$$
\text { توجيه القراءة وتفضيلها. }
$$

اعتدّ الأخفش بقراءة نافع كثبراً، فهو في الغالب يقراً بقراءته، وفضّل مرّة قراءة الكسائي، وهي في أصلها قراءة الإمام علي(رضي الله عنه) وأنس وابن عباس

$$
\text { وابن مسعود، مرفوعة إلى النبي صلوات الله عليه وسلم. }
$$

فاستُعيرت هنا للشدّة والصبر والتجلّد)). (ابن عادل، 1998 صفحة 243/10).

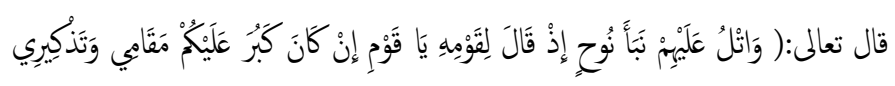

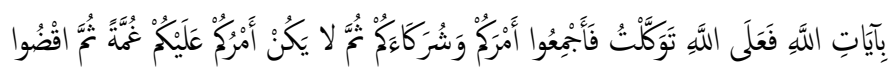

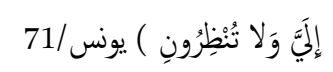

قرأ الأخفش" فأمعوا" بقطع الممزة، من الفعل" أبمع ومَن القِّاء مَن قراً بوصل

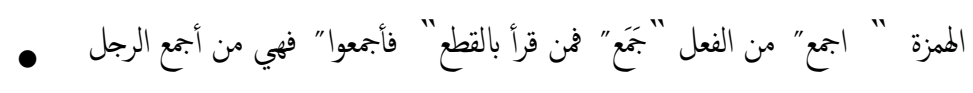
الشيء إذا عزم عليه ونواه. ومن قرأ بالوصل في الألف وفتح الميم" فأمَموا" فهو من

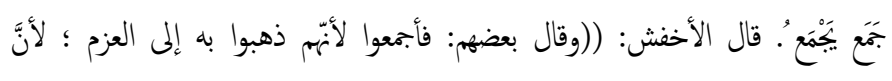
العرب تقول: أجمعت "مري ، أجمعتُ على أن أقول كذا وكذا، أي: عزمتُ عليه وبالمقطوع نقرأ)). (الأخفش، 1981 صفحة 346/2)، وينظر: (ابن مجاهد، 1972 صفحة 328) و (ابن جني، 1386 هجري صفحة 314/1) و (ابن الجزري، 2002 صفحة 286/2). ونقل النحاس ما ذهب إليه الفرّاء من أنَّ الإجحاع هو الإعداد والعزيمة على الأمر ، كما نقل قول المبرّد فقال: (قال الفراء : معناه وادعوا شركاءك، قال: والإجحاعُ : الإعداد والعزيمة على الأمر. وقال أبو العباس: هو محولٌ على المعنى؛ لأنّ معنى" أبمعوا" و" اجمعوا" واحد )). (النحاس، 2004 صفحة 487/1)، وينظر: (الفراء، 1999 صفحة 473/1). وبيّن أبن خالويه جحةّ من قرأ بقطع الألف ويجة من قرأ بالوصل فقال: ((يقراً بقطع الألف ووصلها، فالحجّة لمن قطع؛ أنَّهُ أخذه من قولمم: أبمعت على الأمر: إذا لها أحكته وعزمت عليه ......والحجّة لمن وصل: أنّه أخذه من قولم: جمعت ......فهنا من جمعتُ لا من أبمعت)). (ابن خالويه، 1999 صفحة 103). ونقل صاحب اللباب ما جاء به صاحب اللوامح فقال: ((قال صاحب اللوامح: أجمعت

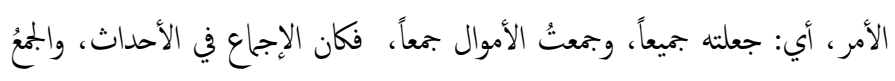
في الأعيان، وقد يُستعمل كل واحد مكان الآخر)). (ابن عادل، 1998 صفحة . $(378 / 10$ 


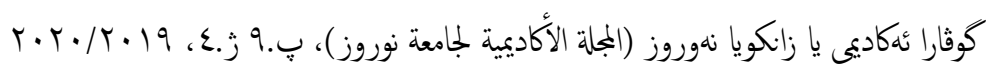

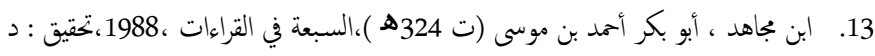

. شوقي ضيف ،ط3،دار المعارف، - القاهرة .

14. ابن منظور، جال الدين محمد بن مكرم الأصاري(ت711هـ)،2004،لسان العرب،دار

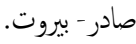

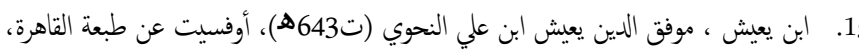

$$
\text { شرح المفصل ، عالم الكتب - بيروت. }
$$

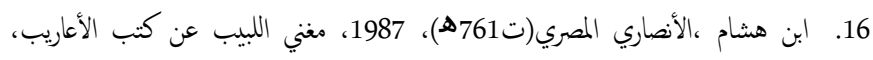

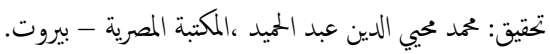

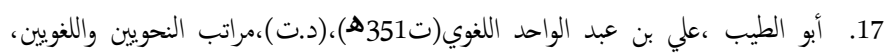

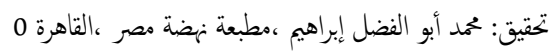

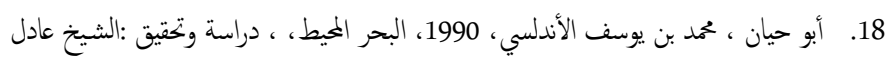

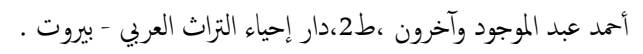

19. أبو زرعة ، عبد الرمن بن محمد بن زنجلة(ت، 400 هـ)، 1974 ، حجة القراءات ، تحتيق:

سعيد الأفغاني ،1ط،مؤسسة الرسالة - بيروت.

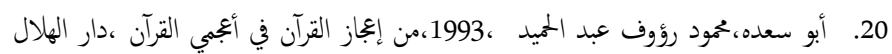

، القاهرة

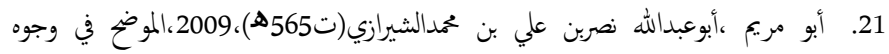

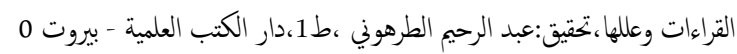

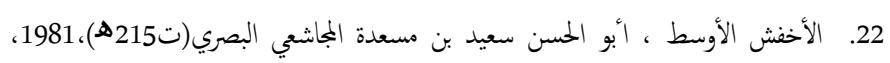

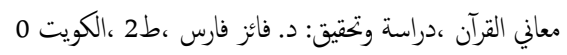

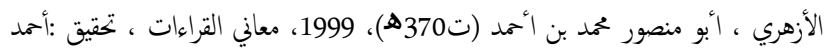

فريد المزيد ،دار الكتب العلمية - بيروت.

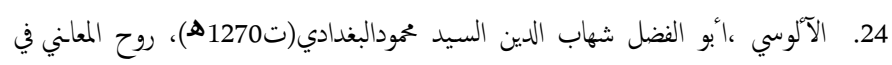

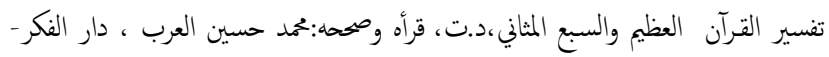

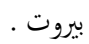

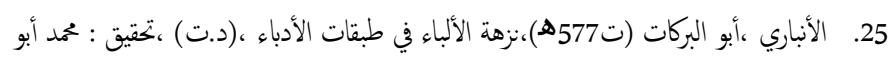

$$
\text { الفضل إبراهيم ،دار نهضة مصر للطبع والنشر ،القاهر } 0
$$

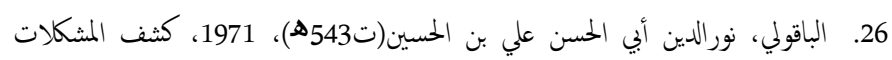

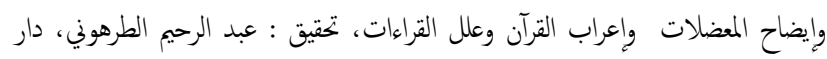

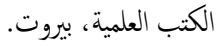

27. البيضاوي ، ناصرالدين أبو سعيدعبداله (ت791هـ)، 1998 ، أنوار التنزيل وأسرار

التأويل،ط1، دار الكتب العلمية - بيروت.

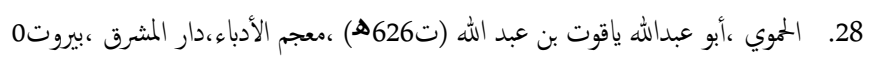

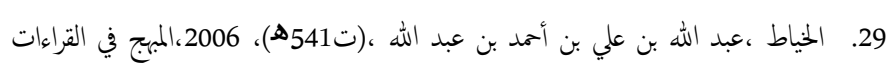

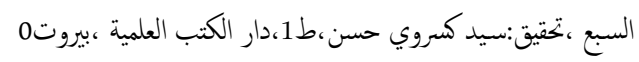

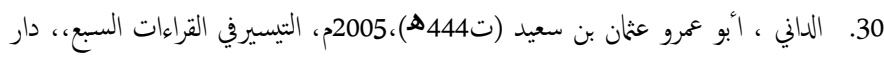

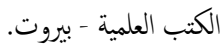

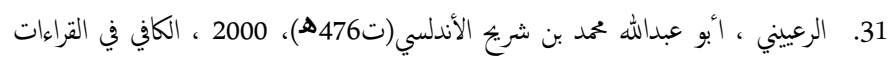
السبع ،تحقيق: أحمد محمود عبدالسميع الشافي ،ط1، 1دار الكتب العلمية - بيروت.
إن تعليل الظواهر اللغويّة عند الأخفش كانت تعليلات لغويّة مضة ، تعتمد على السياق الحالي والمقالي (الواقع اللغوي) ، ولم تظهر النزعة الفلسفية في تعليلاته

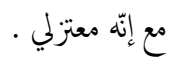

لم يكن الأخفش متحيزا لمذهبه البصري فكان بصريا ،وكوفيا ،ومستقلا أيضا في آراهه ما أثرى المذهب البصري ، وركز دعائم المذهب الكوفي ،وأوضح سعة وبلاغة العربية ،فكان الأخفش رجل علم بصدق وإمام العربية بحق.

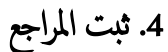

- ابن إدريس، أبو بكر أحمد بن عبيد الله ،(من علماء القرن الرابع

الهجري)،2007،الكتاب المختار في معاني قراءات أهل الأمصار ، تحقيق ودراسة: د.عبدالعزيز بن حميد بن محدالجهيني ، ط1،مكتبة الرشد - ناشرون،الرياض0 1. ابن الجزري ، أبو الخير محمد بن محد(ت833هـ)، 2002، النشرفي القراءات العشر ، تقديم

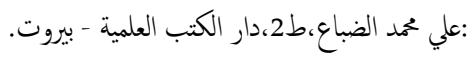
2.

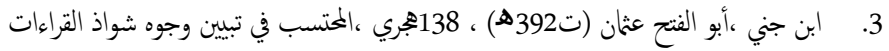

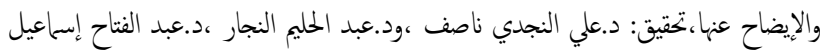

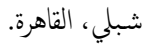
4.

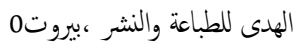

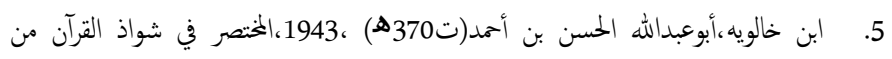

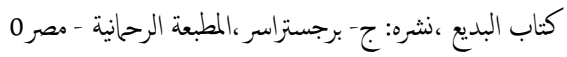

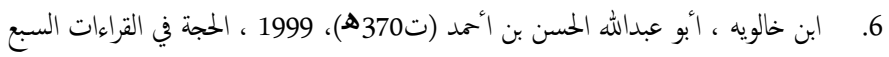

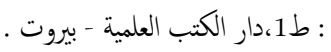

7.

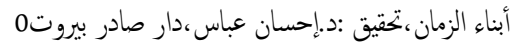
8. ،تحقيق: د.عار أمين الددَّو، 1، بدار البحوث والدراسات الإسلامية - دبي.

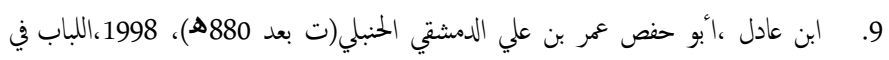

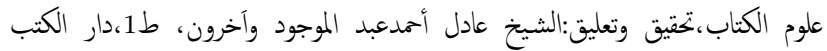
العلمية - بيروت 10. ابن عطية ، أبو محمد عبد المق بن عطية الأندلسي (ت541هـ)، 1974، المحرر الوجيز في تفسير الكتاب العزيز ، تحتيق:أمدالحاج ، القاهرة.

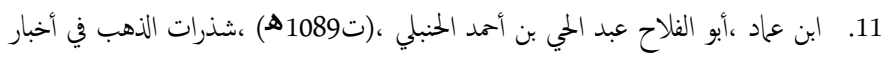

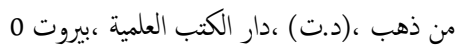

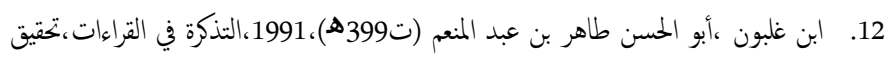

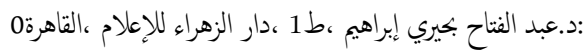




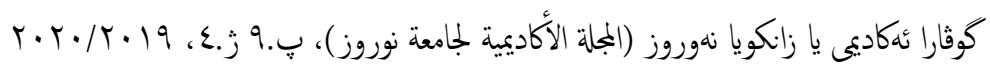

52. الورد ، عبد الأمير ،1975 ، ،16 ، منهج الأخفش الأوسط في الدراسات النحويّة ،

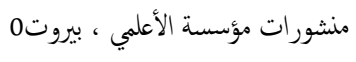

53. تخميس،محمد عبد الدايم ،1996،النفات الإلهية في شرح متن الشاطبية ،ط1،دار المنار ، القاهرة

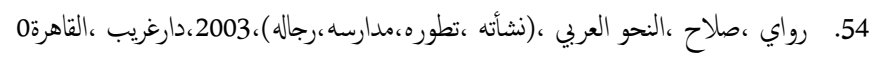

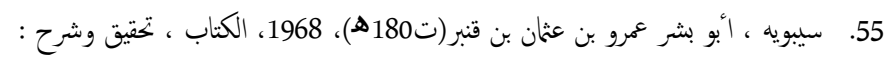
عبد السلام محمد هارون ،ط2، الهيئة المصرية - القاهرة .

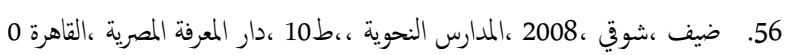

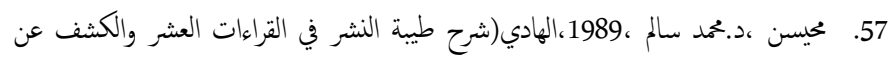

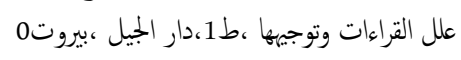

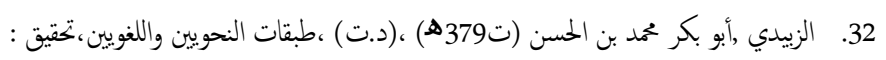
محمد أبو الفضل إبراهيم ،دار المعارف ،مصري

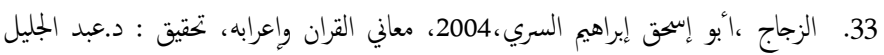

$$
\text { عبده شلبي ،دار الحديث- القاهرة . }
$$

34. الزخشري ، جار الله بن عمر (ت528هـ) ، د.ت. ، الكشاف عن حقائق التنزيل، دار إحياء التزاث العربي - بيروت.

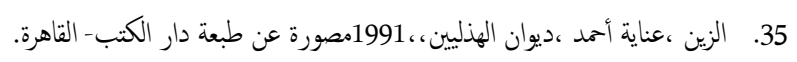

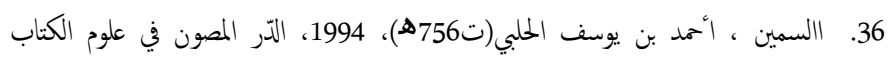
المكنون، تحتيق:علي محمد عوض وآخرون ،ط1، 1ار الكتب العلمية - بيروت.

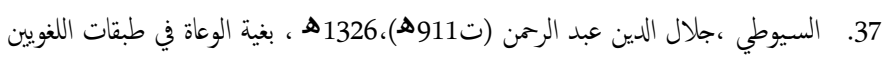

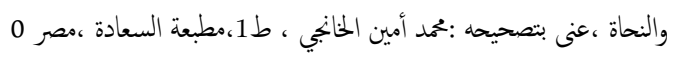

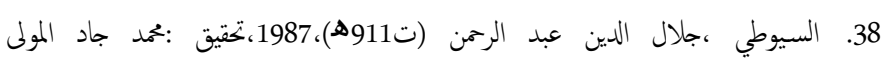
وآخرون، المكتبة العصرية بيروت المبن

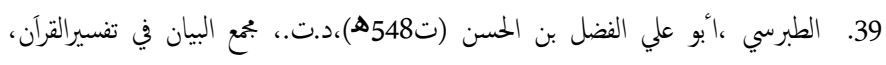

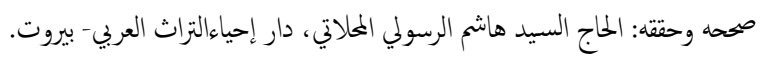

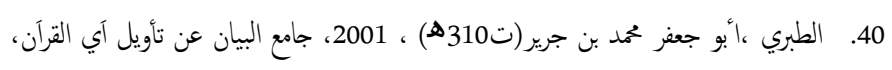

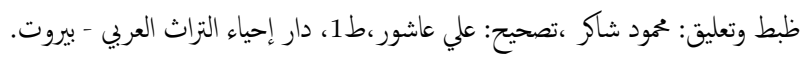

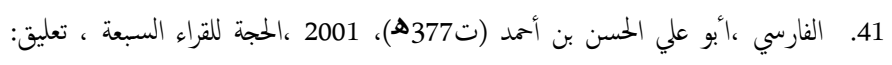
كامل مصطفى الهنداوي ،ط1 ،دار الكتب العلمية - بيروت.

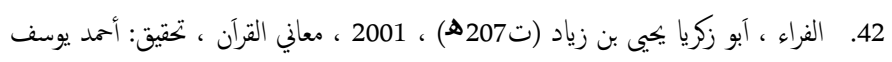
نجلتي ومحمعلي النجار، 36،مطبعة دار الكتب المصرية - القاهرة.

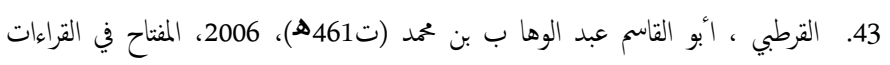

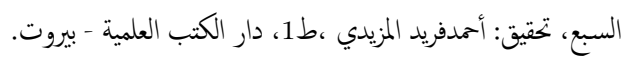

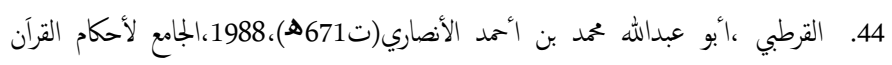

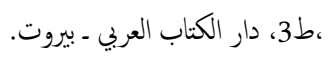

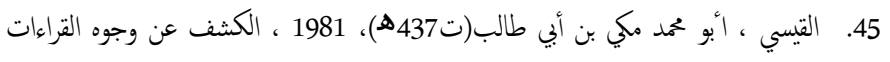

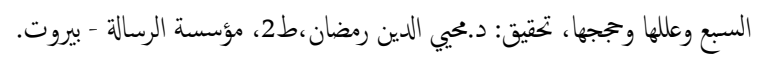

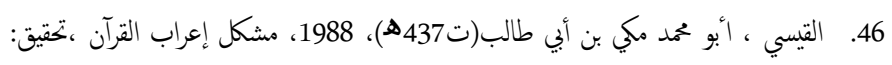
د.اتم صالح الضامن ،ط4، مؤسسة الرسالة - بيروت.

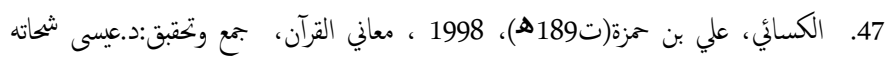
كيسى ،،دار قباء للطباعة- القاهرة.

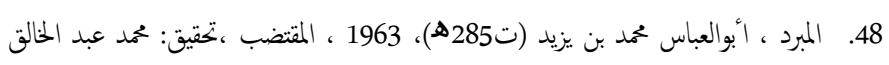

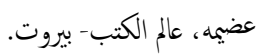

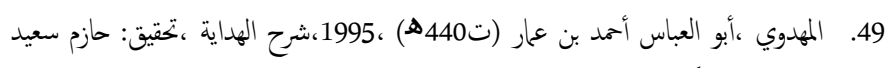

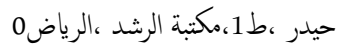

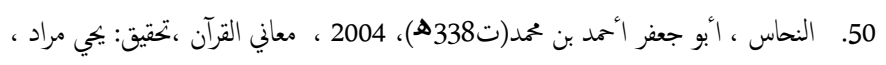
دار الحديث - القاهرة.

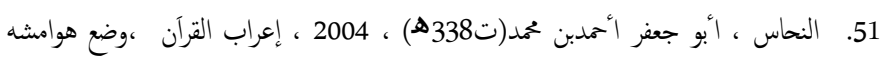
وعلق عله: عبد المنعم خليل إبراهيم،22،دار الكتب العلمية - بيروت. 